\title{
HOOFDSTUK TX.
}

\section{HANDEL EN BANKWEZEN.}

\section{a. Algemeen overzicht.}

Om den tegenwoordigen toestand van den handel van Brazilië, inzonderheid van Rio de Janeiro, de hoofdplaats en tevens de aanzienlijkste handelsplaats van het keizerrijk, te schetsen en daarvan een helder en juist beeld te ontwerpen, is het noodig vooraf een blik te slaan op den toestand van dien handel vóór 20 à 30 jaren.

Als een natuurlijk gevolg van de oude politieke verhouding tusschen moederland en kolonie - eene verhouding welke in dat opzicht vooràl, nog lang nà de independentie van Brazilië bleef voortduren, - was de handel aldaar geheel in handen van de Portugeezen, wier invloed, ofschoon niet meer zóó overwegend als weleer, zich niettemin thans nog meer of min gevoelen laat. En wanneer men verder bedenkt, dat in die tijden van koloniale af hankelijkheid en politieke onmondigheid, welker voortbestaan stelselmatig door de meest bekrompen en kortzichtige staatkunde werd in de hand gewerkt en verzekerd, het niet juist de éérsten van den lande waren, die naar Brazilië trokken, dan kan het feit geene verwondering wekken, dat de handelsstand tot op de laatste helft van deze eeuw schier uitsluitend heeft bestaan uit. weinig ontwikkelde lieden, die in de hoop van in korten tijd fortuin te maken hun geboorteland tijdelijk verlieten.

Geen 25 jaren geleden, was een belangrijk deel van den handel van Rio nog geconcentreerd in handen van eeuige weinige portugeesche huizen, aan het hoofd waarvan lieden stonden die, vroom en onwetend als zij waren zich slechts deden kennen door hunne groote gestrengheid tegenover hunne geëmployeerden, in den regel landslieden, en door het geheimzinnig waas, waarachter zij hunne zaken verborgen hielden. Minder 
door gelukkige speculatiën, waarvoor zij trouwens ook de noodige capaciteiten en handigheid misten, dan wel door oeconomie, de hoofddeugd van het portugeesche volk, waren zij er in geslaagd groote rijkdommen bijeen te garen.

Uiterst gering was het antal braziliaansche firmas, wier leden gewoonlijk bestonden uit lieden van de provinciën Minas Geraes (mineiros), Rio Grande do Sul (rio grandenses) en Sāo Paulo (paulistes), d. w. z. van de afstammelingen der eerste fortuinzoekers uit het koloniale tijdperk. Hun werkkring bepaalde zich hoofdzakelijk tot den commissie-handel in 's lands producten, zooals koffie, katoen, lijnwaden, xarque of gedroogd vleesch, enz. Van des morgens 6 tot des avonds 10 uur waren zij geregeld op hun post; - eerst met het luiden van de "Aragāo", sloten zij hunne kantoren.

De Brazilianen, van nature uiterst indolent en gemakzuchtig, hebben thans nog een schier onoverwinnelijken afkeer en tegenzin voor den handel. Wanneer zij wegens gemis aan kapitaal geen fazenda kunnen exploiteeren, - geen "lavradores" kunnen zijn, dan geven zij de voorkeur aan eene kleine ambtelijke betrekking, hoe gering ook bezoldigd, boven het bedrijvige leven in handel of industrie.

Behalve genoemde categoriën van handelaren had men nog kooplieden van verschillende nationaliteiten: engelschen, franschen, duitschers en belgen, die allen zonder onderscheid aangeduid werden en nog worden onder den algemeenen naam "inglezes" en wier handelshuizen, waarvan verscheidene nog onder dezelfde firma bestaan, zich hoofdzakelijk inlieten met den importhandel. Deze volgden niet de portugeesche gewoonte, maar ontsloten hunne handelshuizen eerst om 9 uur des morgens, om "das Geschäft" in den regel tegen 4 uur's middags te beëindigen. Zij woonden ook niet in de stad, maar daarbuiten in de meer gezonde buitenwijken. Over het algemeen wisten zij mér van het leven te genieten, dan hunne portugeesche of braziliaansche collegas, die nog te veel aan de voorvaderlijke gewoonten verslaafd waren, om hun voorbeeld te volgen. Niettemin werd de opinie der vreemdelingen, zoowel in zaken als in het dagelijksch leven, zéér op prijs gesteld en is het niet onwaarschijnlijk dat het eigenaardige, echt braziliaansche dicton: Para inglez ver, 1 van die tijden dagteekent.

1 Opdat de vreemdeling het moge zieu" of "voor de buiteawacht." 
De scheepvaart, waaraan door de Brazilianen al zeer weinig werd deelgenomen, geschiedde uitsluitend met zeilschepen, zoodat men toen maanden noodig had om een afstand af te leggen, welke thans nauwelijks zooveel weken vereischt.

Het landtransport was mede nog zeer primitief en kon slechts geschieden door tusschenkomst van de tropeiros, die met hunne muilezels (mulas cargueiras) de producten uit de binnenlanden afvoerden, en daarheen het noodige brachten langs onmogelijke bergwegen, welke oin zoo te zeggen langzamerhand en door de elkander opvolgende transporten zelven werden gebaand. Thans kunnen die tropeiros hun bedrijf slechts uitoefenen dáár waar de locomotief zich nog niet heeft vertoond, d. w. z. in het binnenland, tusschen de ondernemingen of fazendas en de stations van den spoorweg.

Het is een eigenaardig gezicht, een karavaan van die op vreemde en samengestelde wijze opgetuigde dieren te zien, één voor één stappende achter de "mula da cabeçada, die hier de plaats inneemt van de "petemoei" of "madrinha". 1 Versierd met een hoofdstel vol zilveren of koperen belletjes, wijst zij den troep den juisten weg aan. Een muilezel draagt niet meer dan 2 zakken elk van 60 kilos, aan elken kant van het zadel, dat in zijn geheel "cangalha" wordt genoemd; doch uit de volgende stukken of onderdeelen is samengesteld: op den rug van het dier wordt eerst een van een zeker rietsoort (tabua) gevlochten matje of esteira gelegd; dárop plaatst men, ten einde de drukking te verzachten, een zadeltje van droog riet (capim membeca) van ongeveer één palm dikte. Daarboven komt dan het houten zadel, met hoogen zadelknop, 't welk gedekt wordt door een lederen kap of capa; hierover hangt men de "broacca", bestaande uit twee lederen, met riemen of touwen aan elkander verbonden enveloppen, waarin de koffiezakken geborgen worden. Instede van lederen enveloppen gebruikt men ook vaak twee op dezelfde wijze aan elkander verbonden manden (jacazes) van gevlochten bamboe (taquara). Ten einde de zakken beter tegen regen en vochtigheid te beschermen, plaatst men over het geheel nog een overtrek (sobrecarga) van geteerd zeildoek of ongelooid leder. Dat met het oog op het bergachtig terrein de "cangalha" stevig aan het dier wordt bevestigd,

1 De "madrinha" is de muilezelin of de merrie, waarombeen de muildieren en paarden blijven grazen, wanneer zij vrij in de "pastos" of weidegronden zijn. De petemoei is herkenbaar aan het belletje dat zij onder den hals draagt. 
door middel van buikriemen, borsttuig en broek, behoeft nauwelijks gezegd te worden.

Het is duidelijk, dat de handel, op die wijze gevoed, zich niet kon onderscheiden door die rustelooze bedrijvigheid, welke thans in de hoofdplaats van het rijk wordt opgemerkt. Terwijl men thans nauwelijks 12 uren behoeft om bv. een afstand van Barbacena naar Rio af te leggen, (379 kilom.), had men dáárvoor vroeger méér dan een maand noodig. In den handel ging alles meer bedaard, meer afgemeten toe. Het "time is money" was nog geen werkelijkheid geworden. Het verkeer tusschen de oude en nieuwe wereld, tusschen Noord- en Zuid-Amerika was nog uiterst beperkt. Men kreeg nog niet zoo dikwijls en zoo geregeld de berichten van die landen. De aankomst van een vaartuig was dan ook voor de burgerij een evenement. Van dáar, dat de thans nog slechts in naam bestaande "Caes dos Mineiros", de toenmalige landing-, los- en laadplaats, het middelpunt van de bedrijvigheid was, en voor een groot deel der stadsbevolking de grootste aantrekkelijkheid bezat.

Voor de sommiteiten van handel en industrie, voor de ambtenaren en militairen, boden daarentegen de toenmaals beroemde, thans nog slechts bij name bekende "Caes de Pharoux", de meest geliefdkoosde wandelplaats. Dáár ontmoette men elkander, dáár besprak men de gebeurtenissen van den dag, dáár kwamen ook de pères de famille vergezeld van hunne dochters en hunne "pequeno caixeiros" die, uit het vaderland aangekomen met eene warme aanbeveling van den "cura da freguezia" (dorpspriester), in den regel werd opgeleid om éénmaal als schoonzoon, deelgenoot in de firma te worden.

Weelde in kleeding en huisraad was in dien tijd onbekend. Men kwam nog zeer eenvoudig, zonder opschik of pretentie voor den dag. Een wit jasje zonder vest, een te huis gemaakte nankin-broek, een los om den hals geslagen doek, bij wijze van halsboord en een strooien hoed van binnenlandsch fabriekaat, maar niettemin "manilha" genoemd, maakten reeds de "full dress" uit, dat "quite correct" genoemd mocht worden zoo men daarbij een paar europeesche schoenen uit den toen beroemden winkel van "Clarck" kon bekostigen. Eerst van lieverlede kwam daarin eenige verandering, teweeggebracht door het jonge Brazilië, de jeugdige "doutores" wier eerzucht het was, voor den dag te komen in een olijfkleurige jas, met groote vergulde knoopen, witte of geele broek, verlakte bottines en hoogen hoed. 
Het is opvallend hoe buitengewoon titelzuchtig de Brazilianen over het algemeen zijn. Het is een ware manie. Zelfs studenten van het laatste jaar, - onverschillig voor welk vak zij zich bekwamen, - worden reeds algemeen aangesproken en erkend als "Senhor Doutor", al is het nog uiterst twijfelachtig of zij dien titel wel éénmaal machtig zullen worden. De hoogste wensch eens vaders, vooral van de moeder, was en is nòg om den zoon als Doutor te kunnen aanspreken. Met innigen trots zal hij dan aan vrienden en magen worden voorgesteld als: "eis meu filho o Doutor Fulano, um socio que me gastou muitos patacas, e si nāo descobriu a polvora é porque ja estava descoberta ${ }^{1}$.

Publieke vermakelijkheden waren in dien tijd slechts voor de meer bemiddelden toegankelijk en bestonden hoofdzakelijk in voorstellingen in de theaters van S. Januario, S. Pedro en Gijmnasio , van spectacle-stukken als: "Naufragio da fragata Medusa", "Ignez de Castro", "Sette infantes de Lara", enz., welke voorstellingen dan geregeld van 8 tot 2 uur 's nachts duurden.

Literatuur of wetenschappen werden bij den vroegeren handelsstand weinig beoefend, ja, voorbeelden kunnen nog aangehaald worden, dat nog 20 jaren geleden geëmployeerden werden ontslagen, wijl zij "lettrados" waren of daarvoor doorgingen.

Geldverdienen was de éénige leus, het éénige wachtwoord. Op welke wijze het verkregen moest worden, werd aan ieders geweten overgelaten. Waren er die fortuin makten in het zweet huns aanschijns; - door oeconomie en spaarzaamheid; van sommigen zegt men, dat de slavensmokkelarij hun rijkste bron van inkomsten uitmaakte, terwijl anderen in weinige jaren hun fortuin heeten gemaakt te hebben, met den importhandel in meel en holle heiligenbeelden, waarin schatten in valsche bankbiljetten verborgen waren. Naar men zegt, moeten de groote fortuinen nog van die tijden dagteekenen.

Die toestand is grootendeels, - en ten goede, - veranderd, dank zij de snellere stoomverbindingen, zoowel met het buitenals met het binnenland, dank zij de uitbreiding van het hoogeren lager onderwijs.

De handel welke zich vroeger beperkte tot een bepaald gedeelte van de oude stad, - tot den omtrek vau de "rua Direita" en "rua dos Ourives", breidt zich thans naar alle

$\left.{ }^{1}\right)$ Mijn zoon, doetor Dinges, een geleerde die mij veel geld gekost heeft, en die het buskruit zou hebben uitgevonden, indien het niet reeds uitgevonden ware. 
kanten uit tot de verstafgelegen buitenwijken, die thans aan het centrum verbonden zijn door een zeer uitgebreid en bewonderenswaardig geadministreerd net van tramways, zooals misschien nergens ter wereld wordt aangetroffen.

De bevolking van Rio de Janeiro, thans geschat op 350 à 400,000 is stellig in de laatste 25 jaren verdrievoudigd, zoodat het leven aldaar zeer duur geworden is. De huurprijzen der woningen en pakhuizen zijn enorm gestegen. Voor de koffiehuizen op goede standen bv. betaalt men 300 tot 500 milreis per maand huur, terwijl in de rua do Ouvidor, de "Kalverstraat" of "Hoogstraat" van Rio de Janeiro, localen voor dat doel verhuurd worden tot 1000 milreis per maand, behalve het sleutelgeld of louvas, dat vaak een jaar huur bedraagt. Voor woonhuizen in de buitenwijken betaalt men tusschen de $200-500$ milreis per maand. Het houden van equipage is buiten bereik van verreweg de meeste beurzen, aangezien daarmede eene maandelijksche uitgave van 500-600 milreis gepaard gaat.

Behalve het vleesch dat zeer goed en buitengewoon goedkoop is, zijn de levensmiddelen betrekkelijk duur. Schier alles moet geïmporteerd worden, omdat men de levensbehoeften in de binnenlanden slechts voor eigen of locale consumptie teelt.

Zeer geriefelijk is het, dat de verschillende handelstakken zich in bepaalde straten en wijken hebben geconcentreerd. Zoo is de "rua do Ouvidor" de straat der modes en confections, de "rua de Sete Setembre" die van de schoenmakers en kooplieden in levensmiddelen, de "rua do Rosario" die van de debitanten van xarque of gedroogd vleesch en tevens van de blikslagers, terwijl de koffiehandel zich heeft samengedrongen in de straten S. Bento, Municipal, Benedictinos, Visconde de Inhaúma en de rua da Saude nabij de dokken van Pedro II voor de commissarios en ensaccadores; in de straten S. Pedro, Alfandega en General-Camara voor de exporteurs, en in de ruas da Saude en da Gamboâ voor de "trapicheiros" of eigenaars van de kadepakhuizen, waar al de koffie, welke per boot of vaartuig wordt aangevoerd, tijdelijk wordt opgeschuurd.

Het wetboek van koophandel in Brazilië is in het jaar 1836 door eene daartoe door de Regeering benoemde commissie vervaardigd; als basis zijn gevolgd de Code Napoléon en de naar deze uitgewerkte Spaansche en Portugeesche wetboeken van koophandel.

De yroegere handelsgerechten (tribunaes do commercio de segunda e ultima instancia) zijn sedert 1875 afgeschaft. Thans 
bestaan slechts "Junta's do Commercio" die uitsluitend zich mogen bemoeien met het administratief gedeelte van de handelszaken bv. met het registreeren van handels-contracten, het parafeeren van de handelsboeken enz., aangezien het judicieële gedeelte tot de bevoegdheid behoort van de "Relaçōes" of appèlhoven voor de geheele provincie.

De president, leden en plaatsvervangende leden (supplentes) van de "Junta" zijn kooplieden, voor een tijdvak van 4 jaren gekozen, door hunne kiesgerechtigde collegas, terwijl de door den Keizer te benoemen secretaris een rechtsgeleerde (bacharel) moet zijn.

Omtrent het wisselrecht bestaan nagenoeg dezelfde bepalingen als in Europa.

Uit den volgenden staat, aantoonende de rijksinkomsten gedurende de laatste 25 jaren verkregen van den Uit- en Invoer van goederen, goud en zilver, kan men afleiden hoe belangrijk de buitenlandsche handel van Brazilië zich in de laatste jaren heeft ontwikkeld, niettegenstaande de aanzienlijke lasten op den uit- en invoer van producten en goederen.

\begin{tabular}{|c|c|c|c|}
\hline $\begin{array}{l}\text { Dienst- } \\
\text { jaren. }\end{array}$ & $\begin{array}{l}\text { Uitvoerrechten } \\
\text { in milreis. }\end{array}$ & $\begin{array}{l}\text { Invoerrechten } \\
\text { in milreis. }\end{array}$ & TokLichting. \\
\hline $\begin{array}{l}1857-58 \\
1858-59 \\
1859-60 \\
1860-61 \\
1861-62\end{array}$ & $\begin{array}{l}6,661,891 \\
7,380,070 \\
5,569,627 \\
7,266,289 \\
8,226,810\end{array}$ & $\begin{array}{l}32,213,399 \\
29,021,792 \\
27,247,146 \\
30,027,626 \\
31,365,424\end{array}$ & $\begin{array}{l}\text { Volgens de "Relatorio da Asso- } \\
\text { ciaçāo Commercial do Rio de Janeiro } \\
\text { 1877." }\end{array}$ \\
\hline $\begin{array}{l}1862-63 \\
1863-64 \\
1864-65 \\
1865-66 \\
1866-67 \\
1867-68 \\
1868-69 \\
1869-70 \\
1870-71 \\
1871-72\end{array}$ & $\begin{array}{r}8,344,988 \\
9,081,797 \\
9,663,379 \\
10,967,099 \\
10,768,577 \\
15,368,075 \\
18,608,159 \\
17,843,447 \\
14,915,887 \\
17,229,353\end{array}$ & $\begin{array}{l}27,438,011 \\
30,795,407 \\
34,477,663 \\
33,441,461 \\
37,640,093 \\
35,873,877 \\
45,346,973 \\
52,369,597 \\
52,994,472 \\
58,599,584\end{array}$ & $\begin{array}{l}\text { Volgens de "Proposta e Relatorio } \\
\text { van het Ministerie van Financiën } \\
\text { 1883." }\end{array}$ \\
\hline $\begin{array}{l}1872-73 \\
1873-74 \\
1874-75 \\
1875-76 \\
1876-77 \\
1877-78 \\
1878-79 \\
1879-80 \\
1880-81 \\
1881-82\end{array}$ & $\begin{array}{l}19,337,652 \\
17,345,535 \\
18,770,258 \\
16,206,373 \\
16,310,156 \\
16,342,341 \\
18,138,007 \\
18,542,448 \\
20,434,538 \\
19,353,607\end{array}$ & $\begin{array}{l}60,281,045 \\
56,306,638 \\
55,464,097 \\
54,736,928 \\
53,938,889 \\
56,852,606 \\
59,308,767 \\
64,756,265 \\
67,860,959 \\
72,194,723\end{array}$ & 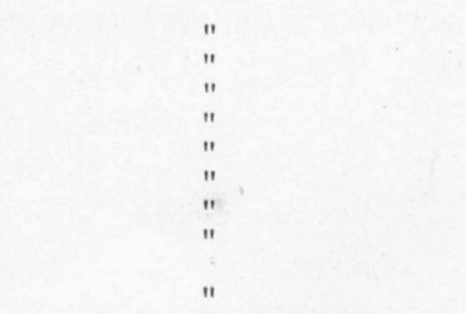 \\
\hline
\end{tabular}


De voornaamste uitvoer-artikelen van het rijk zijn: koffie, suiker, caoutchouc, huiden, tabak, katoen, maté, goud en diamanten, gelijk uit den volgenden staat blijkt (Proposta e Relatorio van 1883).

\begin{tabular}{|c|c|c|c|c|c|c|c|}
\hline & & & & & $\begin{array}{c}1879-1880 \\
\text { waarde } \\
\text { in milreis. }\end{array}$ & $\begin{array}{c}1880-1881 \\
\text { waarde } \\
\text { in milreis. }\end{array}$ & $\begin{array}{c}1881-1882 \\
\text { waarde } \\
\text { in milreis. }\end{array}$ \\
\hline Koffie . . & . & . & . . & . & $126,259,900$ & $126,134,000$ & $104,752,700$ \\
\hline Suiker. & . . & . & . . & . & $31,333,700$ & $25,935,100$ & $36,445,900$ \\
\hline Caoutchoue & . & . & . . & . & $12,242,500$ & $11,855,700$ & $12,005,400$ \\
\hline Huiden . & $\ldots$ & . & . & . & $8,979,900$ & $8,269,500$ & $7,894,100$ \\
\hline Tabak. . & . . & . & . . & . & $7,660,800$ & $7,553,600$ & $7,912,300$ \\
\hline Katoen . & . & . & . . & . & $5,186,700$ & $5,114,600$ & $9,662,300$ \\
\hline Maté . & . & . & . . & . & $2,521,900$ & $2,702,100$ & $2,697,800$ \\
\hline Cacao . . & . . & . & . . & . & $1,002,500$ & 704,600 & 985,000 \\
\hline Castanha do & Pará & . & . . & . & $1,473,800$ & $1,112,700$ & $1,052,000$ \\
\hline Diamanten & . . & & . . & . & $1,007,100$ & $1,307,500$ & 861,200 \\
\hline Arak . . & . . & & . . & . & 336,500 & 309,400 & 281,200 \\
\hline Vezelstoffen & (cabel & & crina & . & 309,500 & 275,800 & 334,100 \\
\hline Tapioca . & . . & & . & & 335,000 & 267,000 & 107,600 \\
\hline Vlas . . & . . & & $\cdot$ & & 138,800 & 142,500 & 151,200 \\
\hline \multirow{2}{*}{\multicolumn{5}{|c|}{ Diverse producten (w. o. goud) }} & $23,140,200$ & $41,883,600$ & $31,567,000$ \\
\hline & & & & & $221,928,800$ & $233,567,700$ & $216,709,800$ \\
\hline
\end{tabular}

De voornaamste invoer-artikelen bestaan in: lijnwaden, zijde, gemaakte kleederen en koffiezakken; porcelein, kristal en glaswerk; meubels, bijouteriën, goud en zilverwerken; wijnen, bieren, likeuren en minerale wateren; boter, kaas, olijfolie en verduurzaamde leveusmiddelen; rijst, meel, aardappelen en europeesche vruchten; thee, specerijen; steenkolen en machineriën; petroleum, teer, portland cement, enz. - waarvan Engeland, Frankrijk, de Vereenigde Staten, Duitschland, Portugal, de Argentijnsche republiek en België de grootste contingenten opleveren.

Uit den volgenden staat kan men zien welk aandeel de verschillende maritieme provinciën van Brazilië hebben in den algemeenen In- en Uitvoer gedurende de dienstjaren 1879/80 tot 1881/82. 


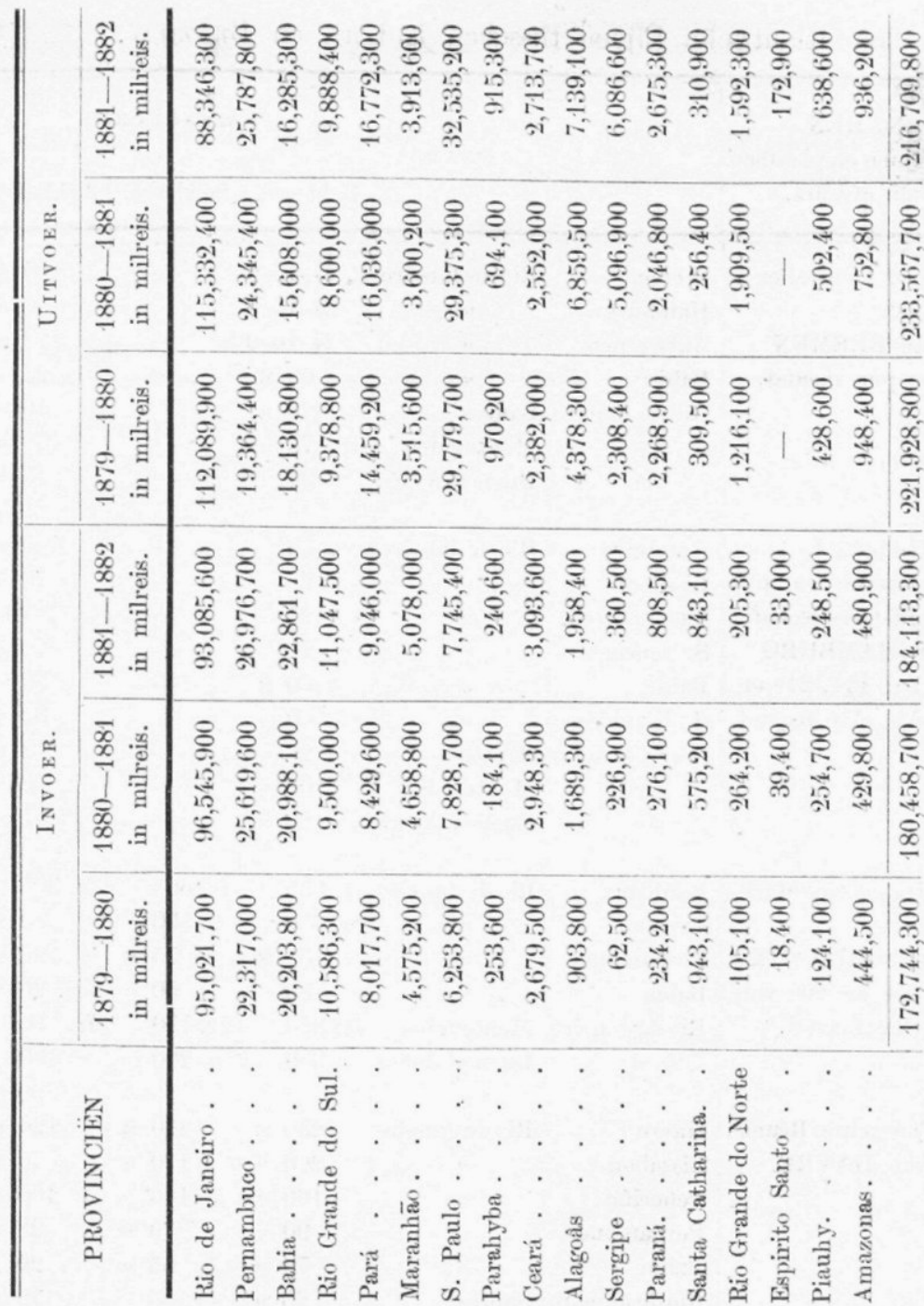

De stoomvaartverbindingen tusschen Brazilië en Europa, Noord- en Centraal-Amerika zijn dan ook in de laatste jaren zéér toegenomen.

Met het oog op de weinige bekendheid welke men ten onzent heeft van de verschillende middelen van gemeenschap tusschen Europa en Brazilië, acht ik het niet overbodig, hieronder een staat te voegen, houdende aantooning van de bestaande stoomvaartlijnen, met de passageprijzen van de verschillende aanlegplaatsen naar Rio de Janeiro enz., benevens eene berekening van de waarde van eenige europeesche munten volgens den koers van Rio op Londen. 
Transatlantische Lijnen tusschen Europa en BraziLLE.

\begin{tabular}{|c|c|c|c|c|c|}
\hline \multirow{2}{*}{$\begin{array}{c}\text { NAMFN } \\
\text { der Lijnen en plaatsen } \\
\text { van afvaart. }\end{array}$} & \multirow{2}{*}{ VAN } & \multirow{2}{*}{$N A A R$} & \multicolumn{3}{|c|}{ PASSAGEPRIJS } \\
\hline & & & le klasse. & 2e klasse. & 3e klasse. \\
\hline $\begin{array}{l}\text { 1. Nord-Deutscher } \\
\text { Lloyd. } \\
\text { van BREMEN } \\
\text { ééns per maand. }\end{array}$ & $\begin{array}{l}\text { Bremen } \\
\text { Hamburg } \\
\text { Antwerpen } \\
\text { Bahia } \\
\text { Rio de Janeiro } \\
\quad \text { " }\end{array}$ & $\begin{array}{c}\text { Rio de Janeiro } \\
" " \\
" \\
\text { Santos } \\
\text { Montevideo } \\
\text { Buenos Ayres }\end{array}$ & $\begin{array}{c}£ .24-15-0 \\
24-15-0 \\
24-10-0 \\
60 \mathrm{~s} \\
20 " \\
75 " \\
90 "\end{array}$ & $\begin{array}{l}- \\
- \\
- \\
- \\
-\end{array}$ & $\begin{aligned} & 100 \& \\
& 100 " \\
& 100 " \\
& 25 " \\
& 10 " \\
& 40 " \\
& 45 "\end{aligned}$ \\
\hline $\begin{array}{l}\text { 2. Hamb. Süd.-Ame- } \\
\text { rikanische Dampff- } \\
\text { sehiff-Gesellschaft. } \\
\text { van HAMBURG } \\
\text { den } 5^{\mathrm{u}}, 13^{\mathrm{n}}, 21^{\mathrm{u}} \text { en } \\
\text { 30n van elke maand. }\end{array}$ & $\begin{array}{l}\text { Hamburg } \\
\text { Lissabon } \\
\text { Azorische eil. } \\
\text { S. Vincent } \\
\text { Bahia } \\
\text { S. Francisco } \\
\text { Rio de Janeiro } \\
\quad " \\
\text { " }\end{array}$ & $\begin{array}{c}\text { Rio de Janeiro } \\
" \\
" \\
" \\
. \\
" \\
\text { Santos } \\
\text { Montevideo } \\
\text { Buenos Ayres }\end{array}$ & $\begin{array}{r}£ 30 \\
" 25 \\
" 27 \\
" 20 \\
60 \text { s } \\
60 " \\
25 " \\
100 " \\
120 "\end{array}$ & $\begin{array}{l}- \\
- \\
- \\
- \\
- \\
- \\
-\end{array}$ & $\begin{array}{c}100 " \\
70 " \\
£ 7-10-0 \\
70 \mathrm{~s} \\
30 " \\
30 " \\
12 " \\
40 " \\
45 "\end{array}$ \\
\hline $\begin{array}{l}\text { 3. Messageries Mari- } \\
\text { times. } \\
\text { van BORDEAUX } \\
\text { den } 5^{\mathrm{n}} \text { en } 20^{\mathrm{n}} \text { van } \\
\text { elke maand. }\end{array}$ & \begin{tabular}{l} 
Bordeaux \\
Lissabon \\
Pernambuco \\
Bahia \\
Rio de Janeiro \\
\multicolumn{1}{c}{$"$}
\end{tabular} & $\begin{array}{c}\text { Rio de Janeiro } \\
" \\
" \\
" \\
\text { Montevideo } \\
\text { Buenos Ayres }\end{array}$ & $\begin{array}{r}\text { fr. } 855 \\
\text { " } 750 \\
100 \$ \\
80 " \\
\text { fr. } 310 \\
\text { " } 350\end{array}$ & $\begin{array}{r}\text { fr. } 605 \\
\text { " } 500 \\
75 \$ \\
60 \quad " \\
\text { fr. } 170 \\
" 200\end{array}$ & $\begin{array}{r}\text { fr. } 305 \\
80 \$ \\
28 " \\
20 " \\
\text { fr. } 90 \\
\text { " } 100\end{array}$ \\
\hline $\begin{array}{l}\text { 4. Chargeurs Réunis. } \\
\text { van HAVRE. }\end{array}$ & \begin{tabular}{l} 
Havre \\
Lissabon \\
Teneriffe \\
Pernambuco \\
Bahia \\
Riode Janeiro \\
$\quad$ " \\
\multicolumn{1}{|c}{}
\end{tabular} & $\begin{array}{c}\text { Rio de Janeiro } \\
" \\
" \\
" \\
" \\
\text { Santos } \\
\text { Montevideo } \\
\text { Buenos Ayres }\end{array}$ & $\begin{array}{r}250 \$ \\
200 " \\
160 " \\
90 " \\
70 " \\
25 " \\
100 " \\
100 "\end{array}$ & $\begin{array}{l}220 \$ \\
170 " \\
140 " \\
70 " \\
55 " \\
\overline{70 "} \\
70 "\end{array}$ & $\begin{array}{r}120 " \\
75 " \\
100 " \\
28 " \\
20 " \\
10 " \\
40 " \\
40 "\end{array}$ \\
\hline $\begin{array}{l}\text { 5. Société Générale de } \\
\text { Transports Mariti- } \\
\text { mes a Vapeur. } \\
\text { van MARSEILLE } \\
\text { ongeveer den } 14^{\mathrm{n}} \text { en } \\
29^{\mathrm{n}} \text { van elke maand. }\end{array}$ & $\begin{array}{l}\text { Marseille } \\
\text { Genua } \\
\text { Napels } \\
\text { Rio de Janeiro } \\
\quad \text { " }\end{array}$ & $\begin{array}{c}\text { Rio de Janeiro } \\
\qquad " \\
\text { Montevideo } \\
\text { Buenos Ayres }\end{array}$ & $\begin{array}{l}\text { fr. } 750 \\
" 750 \\
" 800 \\
100 \mathrm{~s} \\
100 "\end{array}$ & $\begin{array}{r}\text { fr. } 600 \\
" 600 \\
" 650 \\
75 \$ \\
75 "\end{array}$ & $\begin{array}{r}100 " \\
100 " \\
110 " \\
40 " \\
40 "\end{array}$ \\
\hline $\begin{array}{l}\text { 6. Oesterreich-Un- } \\
\text { garische-Lloyd. } \\
\text { van TRIFST } \\
\text { ongeveer den 10n van } \\
\text { elke maand. }\end{array}$ & $\begin{array}{l}\text { Triëst } \\
\text { Napels } \\
\text { Pernambuco } \\
\text { Bahia } \\
\text { Rio de Janeiro }\end{array}$ & $\begin{array}{c}\text { Rio de Janeiro } \\
" \\
" \\
" \\
\text { Saustosoded from }\end{array}$ & $\begin{array}{rr}\text { fl. } 321 \\
" \quad 334 \\
" \quad 60 \\
" \quad 28\end{array}$ & $\begin{array}{rr}\text { fl. } & 214 \\
\text { " } 220 \\
\text { " } 40 \\
\text { " } 18\end{array}$ & $\begin{array}{rr}\text { fl. } & 80 \\
\text { " } & 90 \\
\text { " } & 6 \\
\text { " } & 3\end{array}$ \\
\hline
\end{tabular}




\begin{tabular}{|c|c|c|c|c|c|}
\hline \multirow{2}{*}{$\begin{array}{c}\text { NAMEN } \\
\text { der Lijnen en plaatsen } \\
\text { van afvaart. }\end{array}$} & \multirow{2}{*}{$\mathrm{VAN}$} & \multirow{2}{*}{$\mathrm{NAAR}$} & \multicolumn{3}{|c|}{ PASSAGEPRUS } \\
\hline & & & le klasse. & 2e klasse. & 3e klasse. \\
\hline $\begin{array}{l}\text { 2. Societi G. B. La- } \\
\text { varello en Co. } \\
\text { van GENUA } \\
\text { eens per maand, on- } \\
\text { bepaald. }\end{array}$ & $\begin{array}{l}\text { Genua } \\
\text { Napels } \\
\text { Marseille } \\
\text { Riode Juneiro } \\
\quad \text { " }\end{array}$ & $\begin{array}{c}\text { Rio de Janeiro } \\
" " \\
\text { Montevideo } \\
\text { Buenos Ayres }\end{array}$ & $\begin{array}{r}\text { fr. } 800 \\
" 850 \\
" 800 \\
80 \$ \\
80 "\end{array}$ & $\begin{array}{r}\text { fr. } 600 \\
" 650 \\
" 600 \\
60 \$ \\
\\
60 "\end{array}$ & $\begin{array}{r}100 \$ \\
110 " \\
100 " \\
30 " \\
40 "\end{array}$ \\
\hline $\begin{array}{l}\text { 8. Societá Roceo Pi- } \\
\text { aggio \& figlio. } \\
\text { van GENUA } \\
\text { eens p. maand, onbep. }\end{array}$ & $\begin{array}{l}\text { Genua } \\
\text { Napels } \\
\text { Marseille }\end{array}$ & $\begin{array}{c}\text { Rio de Janeiro } \\
" \\
"\end{array}$ & $\begin{array}{l}300 " \\
350 " \\
300 "\end{array}$ & $\begin{array}{l}220 " \\
247 " \\
220 "\end{array}$ & $\begin{array}{r}95 " \\
102 " \\
90 "\end{array}$ \\
\hline $\begin{array}{l}\text { 9. Societá Schiaffino. } \\
\text { van GENUA } \\
\text { eens per maand, on- } \\
\text { bepaald. }\end{array}$ & $\begin{array}{l}\text { Genua } \\
\text { Napels } \\
\text { Marseille }\end{array}$ & $\begin{array}{l}" \\
" 1\end{array}$ & $\begin{array}{l}- \\
-\end{array}$ & $\begin{array}{l}- \\
-\end{array}$ & - \\
\hline $\begin{array}{l}\text { 10. Sociéti di Trans- } \\
\text { porti Maritimmi } \\
\text { Raggio \& Co. } \\
\text { van GENUA } \\
\text { eens p. maand, onbep. }\end{array}$ & $\begin{array}{l}\text { Genua } \\
\text { Napels } \\
\text { Marseille }\end{array}$ & $\begin{array}{l}" \\
" \\
"\end{array}$ & $\frac{-}{-}$ & $\begin{array}{l}- \\
-\end{array}$ & - \\
\hline $\begin{array}{l}\text { 11. New-Zealand } \\
\text { Shipping Company. } \\
\text { van LONDON } \\
\text { eens per mannd, on- } \\
\text { bepaald. }\end{array}$ & $\begin{array}{l}\text { London } \\
\text { Plymouth } \\
\text { Madeira }\end{array}$ & $\begin{array}{l}\text { " } \\
" \\
\text { ". }\end{array}$ & $\begin{array}{ll}£ & 30 \\
" & 30 \\
" & 25\end{array}$ & $\begin{array}{ll}£ & 20 \\
" & 20 \\
" & 12\end{array}$ & $\begin{array}{rr}£ & 13 \\
" & 13 \\
" & 8\end{array}$ \\
\hline $\begin{array}{l}\text { 12. Vapores Correos } \\
\text { del Marquez del } \\
\text { Campo. } \\
\text { van LIVERPOOL } \\
\text { eens per maand, on- } \\
\text { bepaald. }\end{array}$ & \begin{tabular}{l} 
Liverpool \\
Bordeaux \\
Lissabon \\
Barcelona \\
Valencia \\
Pernambuco \\
Riode Janeiro \\
\multicolumn{1}{c}{ " }
\end{tabular} & $\begin{array}{c}" \\
" \\
" \\
" \\
" \\
" \\
\text { Montevideo } \\
\text { Buenos Ayres }\end{array}$ & $\left\{\begin{array}{c}\text { Pesetas. } \\
700 \\
11 \\
200 \\
250\end{array}\right.$ & $\begin{array}{c}\text { Pesetas. } \\
450 \\
" \\
150 \\
175\end{array}$ & $\begin{array}{c}\text { Pesetas. } \\
180 \\
11 \\
100 \\
125\end{array}$ \\
\hline $\begin{array}{l}\text { 13. Liverpool, Brazil } \\
\text { and River Plate } \\
\text { Mail Steamers. } \\
\text { van LIVERPOOL } \\
\text { den } 5^{\mathrm{n}} \text { en } 20^{\mathrm{n}} \text { van } \\
\text { elke maand. }\end{array}$ & $\begin{array}{l}\text { Liverpool } \\
\text { London } \\
\text { Southampton } \\
\text { Antwerpen } \\
\text { Lissabon } \\
\text { Bahia } \\
\text { Rio deJaneiro } \\
\quad " \\
\text { " }\end{array}$ & \begin{tabular}{|c|} 
Rio de Janeiro \\
$"$ \\
$"$ \\
$"$ \\
$"$ \\
Santos \\
Montevideo \\
Buenos Ayres \\
Downloaded f
\end{tabular} & $\begin{array}{l}£ 30 \\
230 \$ \\
70 " \\
19 \frac{1}{2} " \\
100 " \\
100 " \\
\text { from Brilu.c }\end{array}$ & $\begin{array}{r}- \\
- \\
\overline{-}\end{array}$ & $\begin{array}{r} \pm 12-10 \\
70 \text { s } \\
25 " \\
11 " \\
40 " \\
40 " \\
12: 44: 16 \mathrm{PM}\end{array}$ \\
\hline
\end{tabular}




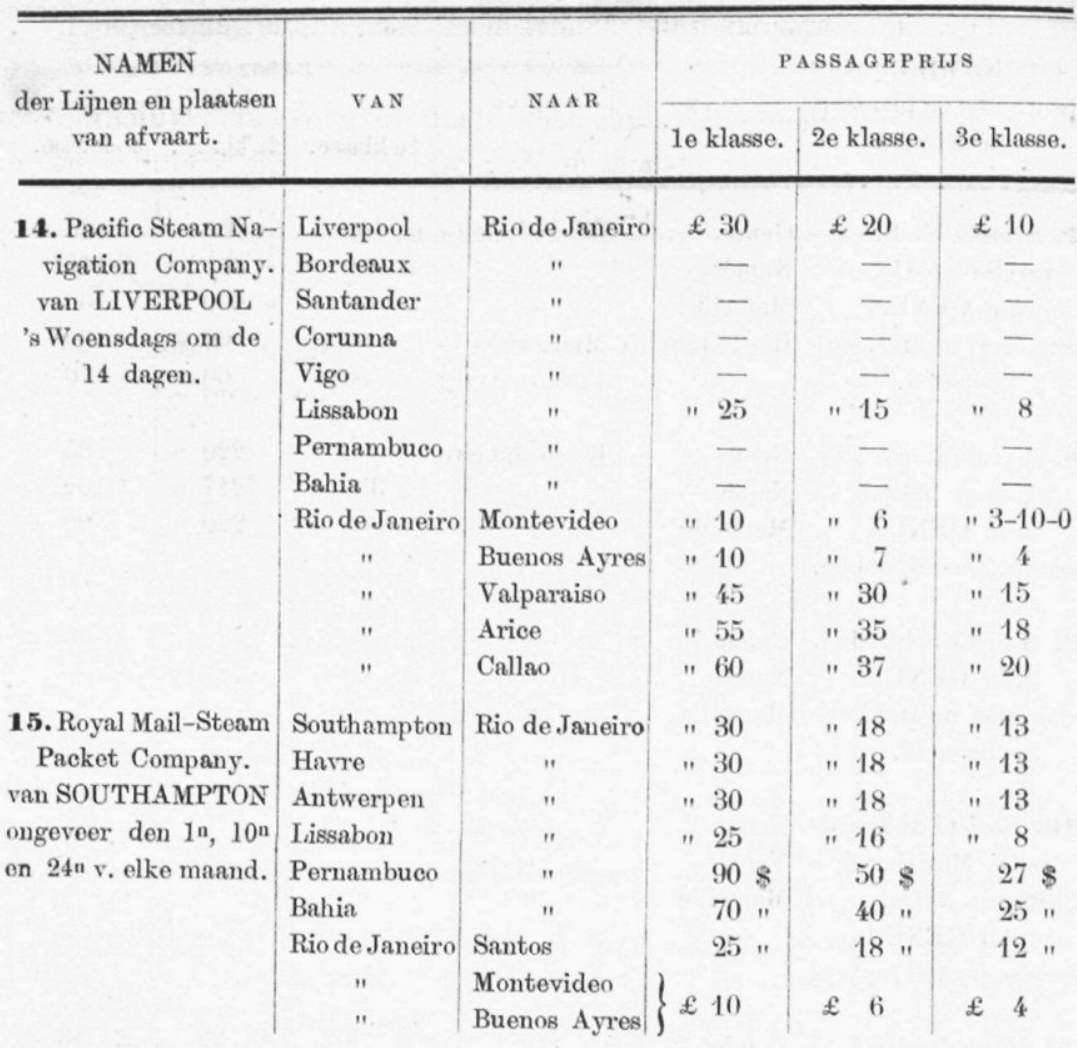

Waarde van de verschillende muntstukken in Milreis volgens den koers van Rio de Janeiro op London.

\begin{tabular}{|c|c|c|c|c|c|c|c|c|c|c|c|}
\hline & & & & 20 & $\mathbf{2 0} \frac{1}{4}$ & $20 \frac{1}{2}$ & $20 \frac{3}{4}$ & 21 & $21 \frac{1}{4}$ & $21 \frac{1}{2}$ & $21 \frac{3}{4}$ \\
\hline 1 florijn. & . & . & & 1,237 & 1,222 & 1,207 & 1,193 & 1,179 & 1,165 & 1,151 & 1,138 \\
\hline 1 frane, lir & re of $p$ & pes $^{a}$ & & 0,472 & 0,466 & 0,460 & 0,454 & 0,449 & 0,444 & 0,439 & 0,434 \\
\hline 1 mark. & . . & . & & 0,729 & 0,720 & 0,711 & 0,702 & 0,694 & 0,686 & 0,678 & 0,670 \\
\hline $1 £$ st. . & . & . & & 12,000 & 11,852 & 11,707 & 11,566 & 11,429 & 11,294 & 11,163 & 11,034 \\
\hline 1 gulden & . & & & 0,993 & 0,981 & 0,969 & 0,957 & 0,946 & 0,935 & 0,924 & 0,913 \\
\hline 1 thaler. & . & & $=$ & 1,768 & 1,746 & 1,724 & 1,704 & 1,684 & 1,664 & 1,645 & 1,626 \\
\hline \multirow[t]{2}{*}{1 dollar. } & . & & $=$ & 2,528 & 2,497 & 2,466 & 2,437 & 2,408 & 2,379 & 2,298 & 2,271 \\
\hline & & & & 22 & $22 \frac{1}{4}$ & $22 \frac{1}{2}$ & $22 \frac{3}{4}$ & 23 & $23 \frac{1}{4}$ & $23 \frac{1}{2}$ & $\begin{array}{c}\text { PARI } \\
\text { of koers } \\
\text { volgens de } \\
\text { intrensieke } \\
\text { waarde. }\end{array}$ \\
\hline 1 florijn. & . . & . & & 1,125 & 1,112 & 1,100 & 1,088 & 1,076 & 1,064 & 1,053 & 0,917 \\
\hline 1 frane, lire & re of $p$ & pesa & & 0,429 & 0,424 & 0,419 & 0,414 & 0,410 & 0,406 & 0,402 & 0,350 \\
\hline I mark. & . & & & 0,662 & 0,654 & 0,647 & 0,640 & 0,633 & 0,626 & 0,621 & 0,540 \\
\hline $1 £$ st. . & . & . & & 10,909 & 10,787 & 10,667 & 10,550 & 10,435 & 10,323 & 10,213 & 8,889 \\
\hline 1 gulden & . & & & 0,903 & 0,893 & 0,883 & 0,873 & 0,864 & 0,854 & 0,845 & 0,736 \\
\hline 1 thaler. & : & & & 1,607 & 1,589 & 1,571 & 1,554 & 1,537 & 1,521 & 1,505 & 1,310 \\
\hline 1 dollar. & & & & 2,245 & 2,220 & $\begin{array}{l}2,196 \\
\text { Downto }\end{array}$ & $\begin{array}{r}2,172 \\
\text { oaded fr }\end{array}$ & $\begin{array}{l}2,148 \\
\text { rom Brill }\end{array}$ & $\begin{array}{r}2,125 \\
\text { L. come4/2 }\end{array}$ & $2 \underset{26 / 2023}{2,102}$ & $\begin{array}{c}1,830 \\
12: 44: 16 \mathrm{PM}\end{array}$ \\
\hline
\end{tabular}


Ook de binnenlaudsche handel heeft zich in de laatste jaren zeer uitgebreid.

De verschillende havenplaatsen staan in geregelde verbinding zoowel met elkander als met de Zuid-Amerikaansche republieken. Twintig stoomvaartmaatscháppijen wordeu daarvoor door het Braziliaansche gouvernement gesubsidieerd met 3,300,600 milreis 's jaars.

De belangrijkheid van den inter-provincialen handel per cabotagem of kustvaart blijkt uit den volgenden staat:

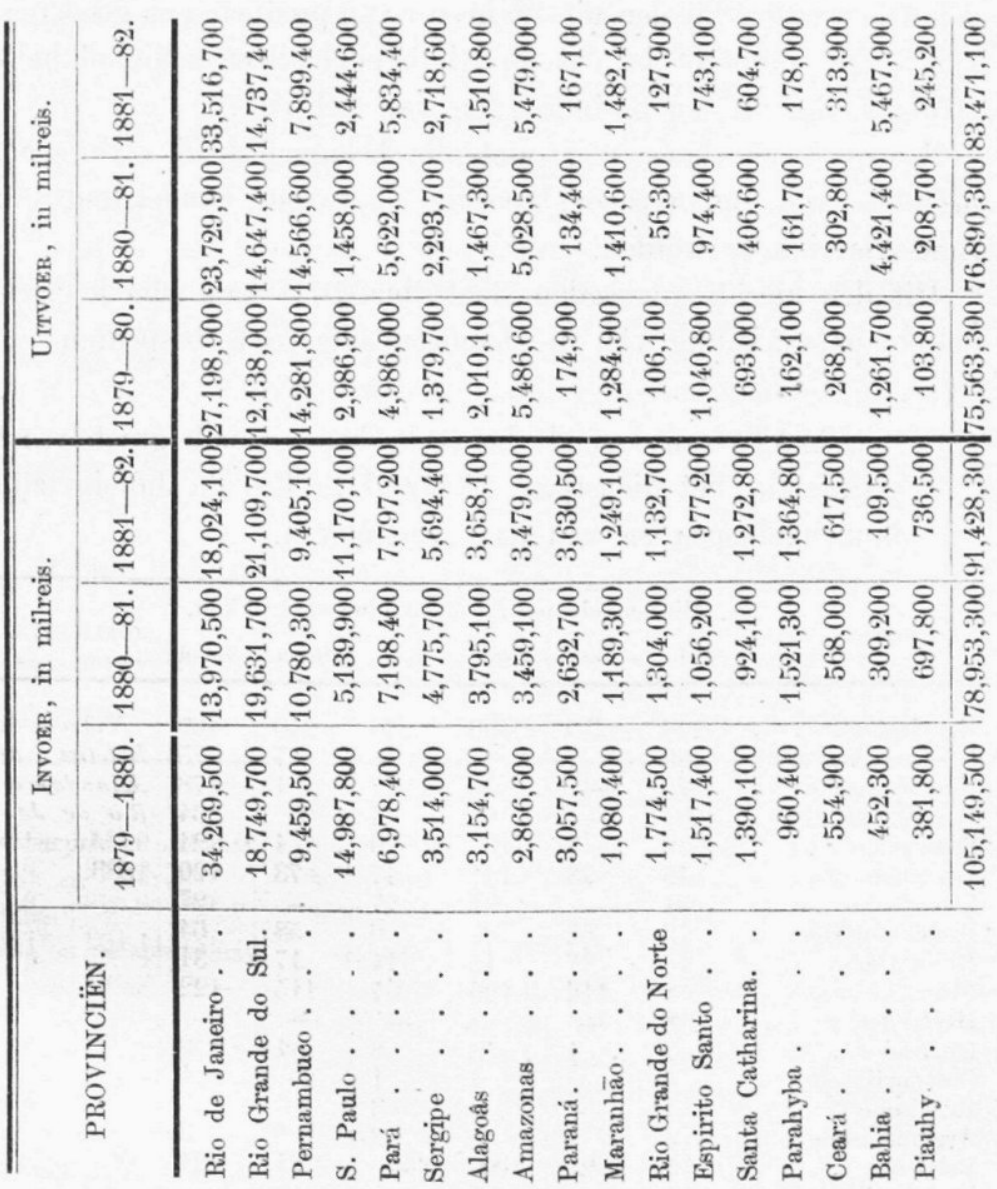

Als export- en importhaven is Rio de Janeiro verreweg de voornaamste.

Ten einde een denkbeeld te geven van den grooten handelsomzet van die plaats, laat ik hieronder volgen een overzicht:

10. van het aantal schepen gedurende 1882/83 te Rio binnengeloopen en van daar vertrokbentloaded from Brill.com04/26/2023 12:44:16PM 
2o. vau de uitroer- en invoerwaarden gedurende de laatste 10 dienstjaren.

30. van de goederen welke in de laatste 5 jaren zijn uitgevoerd

4.0 . " " " " " " " " ingevoerd

$5^{\circ}$. van den nitvoer van de laatste 5 jaren naar de verschillende landen.

60 . van den invoer van de laatste 5 jaren van de verschillende landen, benevens

7o. een staat, waaruit men zien kan, welke hooge rechten geheven worden bij den uit- en invoer van producten en goederen.

Uit die staten blijkt dat de Rio-handel alleen schier de helft oplevert van de douane-inkomsten van het rijk.

Santos heeft thans nog niet die belangrijkheid verkregen, maar is wel op weg om spoedig de tweede handelsstad van Zuid-Amerika te worden.

Uit den hierbij gevoegden staat (blz. 204) kan men de geleidelijke ontwikkeling van die handelsplaats reeds bespeuren.

STAAT, aantoonende hoeveel schepen van de groote vaart gedurende het dienstjaar 1882/83 te Rio de Janeiro zijn binnengeloopen en van daar vertrokken.

\begin{tabular}{|c|c|c|c|c|c|c|c|}
\hline \multirow{2}{*}{ NATIONALITEIT. } & \multicolumn{3}{|c|}{ Binnengeloopen. } & \multicolumn{3}{|c|}{ Weder vertrokken. } & \multirow{2}{*}{ TOELICHTING. } \\
\hline & Zeil. & Stoom. & Totaal. & Zeil. & Stoom. & Totaal. & \\
\hline $\begin{array}{l}\text { Engelsche . } \\
\text { N.-Amerikaansche } \\
\text { Noorweegsche. } \\
\text { Portugeesche . } \\
\text { Spaansche : } \\
\text { Duitsche . } \\
\text { Zweedsche. } \\
\text { Braziliaansche. } \\
\text { Italiaansche . } \\
\text { Fransche } \\
\text { Hollandsche . } \\
\text { Deensche. } \\
\text { Oostenrijksche. } \\
\text { Russische . } \\
\text { Argentijnsche. } \\
\text { Belgische . } \\
\text { Z.-Amerikaansche }\end{array}$ & $\begin{array}{r}248 \\
80 \\
75 \\
67 \\
52 \\
48 \\
31 \\
19 \\
15 \\
8 \\
8 \\
7 \\
4 \\
4 \\
3 \\
1 \\
1 \\
671\end{array}$ & $\begin{array}{r}250 \\
7 \\
- \\
- \\
3 \\
73 \\
-\quad \\
67 \\
27 \\
112 \\
-\quad 1 \\
- \\
- \\
1 \\
25 \\
- \\
566\end{array}$ & $\begin{array}{r}498 \\
87 \\
75 \\
67 \\
55 \\
121 \\
31 \\
86 \\
42 \\
120 \\
8 \\
8 \\
4 \\
4 \\
4 \\
26 \\
1 \\
1237\end{array}$ & $\begin{array}{r}220 \\
68 \\
77 \\
34 \\
20 \\
47 \\
27 \\
6 \\
14 \\
7 \\
-\quad 8 \\
1 \\
3 \\
2 \\
- \\
534\end{array}$ & $\begin{array}{r}249 \\
7 \\
1 \\
- \\
4 \\
73 \\
-58 \\
17 \\
115 \\
- \\
-1 \\
- \\
1 \\
- \\
550\end{array}$ & $\begin{array}{r}469 \\
75 \\
78 \\
34 \\
24 \\
120 \\
27 \\
64 \\
31 \\
122 \\
- \\
9 \\
1 \\
3 \\
3 \\
24 \\
- \\
1084\end{array}$ & $\begin{array}{l}\text { Volgens de } \\
\text { Boletim da } \\
\text { Alfandegado } \\
\text { R.o de Jan. } \\
9 \text {. Augustus } \\
1883 \text {. }\end{array}$ \\
\hline
\end{tabular}

NB. Gedurende de eerste helft van het dienstjaar $1883 / 84$ zijn, blijkens de Boletim van 23 Januari 1884 , te Rio binnengeloopen en van daar vertrokken: 1286 schepen groot $1,437,371$ tomnen van de groote vaart

851 " " 374,045 " " " groote kustvaart 619 " " 2756 " waarvan: 1530 zeil- en 1226 stoomschepen, of 1218 Braziliansche en 1538 vreemde schepen. 
STAAT, aantoonende de waarden van den Uitvoer en Invoer te Rio de Janeiro en de rechten daarvan geheven, gedurende de laatste 10 jaren.

\begin{tabular}{l|r|r|r|r}
\hline $\begin{array}{c}\text { Dienst- } \\
\text { jaren. }\end{array}$ & $\begin{array}{c}\text { Uitvoer in } \\
\text { m. }\end{array}$ milreis. & $\begin{array}{c}\text { Uitvoerrechten } \\
\text { b. } \text { in milreis. }\end{array}$ & $\begin{array}{c}\text { Invoer in } \\
\text { milreis. }\end{array}$ & $\begin{array}{l}\text { Invoerrechten in } \\
\text { d. }\end{array}$ \\
\hline $1873-74$ & $86,995,877$ & $8,045,201$ & $95,385,778$ & $30,703,180$ \\
$1874-75$ & $103,091,352$ & $9,466,171$ & $95,394,885$ & $31,237,180$ \\
$1875-76$ & $100,544,413$ & $9,112,892$ & $97,690,838$ & $30,103,788$ \\
$1876-77$ & $101,047,882$ & $8,608,836$ & $87,392,443$ & $29,438,407$ \\
$1877-78$ & $92,339,465$ & $8,436,412$ & $90,227,430$ & $30,759,092$ \\
$1878-79$ & $106,061,286$ & $9,724,206$ & $91,029,327$ & $31,843,590$ \\
$1879-80$ & $112,089,911$ & $8,732,145$ & $95,021,682$ & $32,565,220$ \\
$1880-81$ & $115,332,445$ & $10,192,402$ & $96,545,928$ & $32,757,828$ \\
$1881-82$ & $88,346,310$ & $7,814,672$ & $93,085,637$ & $32,582,379$ \\
$1882-83$ & $91,489,799$ & $6,944,732$ & $99,196,638$ & $33,623,563$
\end{tabular}

$a$ en $c$. De opgaven van de 5 eerste dienstjaren zijn getrokken uit de Relatorio da Associaçāo Commereial do Rio de Janeiro van 1880 en 1882, die van de 5 laatste van de Boletim da Alfandega do Rio de Janeiro van 25 Juli 1883 No. 12 verbeterde opgave.

$b$ en $d$. De opgaven van de 9 eerste dienstjaren zijn getrokken uit de Boletim da Alfandega do Rio de Janeiro van 5 Maart 1883 bl. 4, die van $1882 / 83$ uit die van 25 Juli 1883.

Uitvoer van Rio de Janeiro volgens de Boletim da Alfandega dd0 25 Juli 1883.

\begin{tabular}{|c|c|c|c|c|c|}
\hline UITVOER VAN : & $\begin{array}{l}1878-79 \\
\text { in milreis. }\end{array}$ & $\begin{array}{l}1879-80 \\
\text { in milreis. }\end{array}$ & $\begin{array}{c}1880-81 \\
\text { in milreis. }\end{array}$ & $\begin{array}{c}1881-82 \\
\text { in milreis. }\end{array}$ & $\begin{array}{l}1882-83 \\
\text { in milreis. }\end{array}$ \\
\hline Koffie . . . . . . & $100,917,767$ & $92,421,576$ & $109,311,555$ & $82,364,162$ & $86,229,583$ \\
\hline Goud in poeder en baren & $1,716,136$ & $1,490,474$ & $1,223,362$ & $1,477,450$ & $1,142,264$ \\
\hline Tabak en Cigaren . . & $1,201,645$ & 796,353 & 708,576 & 652,822 & 886,667 \\
\hline Huiden . . . . & $1,007,959$ & 846,862 & 955,444 & 919,004 & 799,796 \\
\hline Ruwe en geslepen diam. & 621,694 & 467,744 & 768,144 & 423,308 & 287,568 \\
\hline Jacarandá-hout . . . & 196,975 & 337,223 & 380,490 & 332,382 & 426,882 \\
\hline Meel (maïs) . . . & 137,047 & 258,750 & 136,567 & 51,032 & 63,507 \\
\hline Suiker . . . . & 95,824 & 731,623 & 90,767 & $1,015,725$ & 687,370 \\
\hline Brandewijn. . . . & 46,490 & 109,572 & 32,342 & 33,449 & 12,710 \\
\hline Medicinale planten. . & 37,776 & 47,137 & 70,575 & 60,073 & 28,380 \\
\hline \multirow{6}{*}{$\begin{array}{l}\text { Verschillende produc- } \\
\text { ten, w. o. ook goud, } \\
\text { zilver en papiergeld. }\end{array}$} & & a) $14,582,597$ & $1,654,653$ & $1,016,906$ & 925,072 \\
\hline & $106,061,286$ & $112,089,911$ & \multicolumn{3}{|c|}{$115,332,44588,346,31091,489,799$} \\
\hline & Coupons en & papiergeld . & \multicolumn{3}{|l|}{. $11,056,000$} \\
\hline & Goudgeld. & - & \multicolumn{3}{|l|}{. $\quad 3,341,607$} \\
\hline & Zilvergeld & . . . . & \multicolumn{3}{|l|}{. $\quad 45,161$} \\
\hline & Diversen. & - Down loade & 139,829 & & \\
\hline
\end{tabular}


Invoer te Rio de Janerro volgens de Boletim da Alfandega dd. 25 Juli 1883.

INYOER VAN :

\section{\begin{tabular}{|l|l|l|l|l|}
$1888-79$ & $1879-80$ & $1880-81$ & $1881-82$ & $1882-83$
\end{tabular}}

in milreis. in milreis. in milreis. in milreis. in milreis.
Katoen.

Vleesch, visch enz.

Wol .

Plantenвappen

Graven, groenten, zaden

Goud, zilver, platina .

Steenkolen, mineralen

Vlas.

IJzer, staal

Parfumeriën en oliën .

Leder en lederwerk

Machineriën

Specerijen .

Chemische producten

Papier

Zijde

Aarde- en glaswerk

Hout

Koper en koperwerk .

Versche en gedr. vruchten .

Ivoor, paarlmoer, schildpad.

Lood, tin, zink.

Ornamenten

Haar, veeren enz. .

Horloges en uurwerken.

Muziekinstrumenten

Math. phys. en chirurg. instrumenten

Stroo, zeegras, vezelstoffen.

Messen .

Vee .

Diverse artikelen
$19,130,34420,715,61019,852,66419,171,97120,696,904$ $\begin{array}{llllll}9,699,765 & 10,095,284 & 9,167,005 & 8,883,632 & 9,106,150\end{array}$

\begin{tabular}{ll|l|l|l|l}
$7,348,703$ & $8,148,267$ & $7,934,229$ & $7,188,182$ & $7,337,532$
\end{tabular}

\begin{tabular}{l|l|l|l|l|l}
$7,191,676$ & $6,916,434$ & $6,824,595$ & $6,773,523$ & $6,604,177$
\end{tabular}

\begin{tabular}{l|l|l|l|l}
$6,482,746$ & $5,443,952$ & $5,605,084$ & $6,586,110$ & $6,691,122$
\end{tabular}

\begin{tabular}{l|l|l|l|l|l}
$5,542,688$ & $8,506,795$ & $7,355,853$ & $4,534,891$ & $7,997,457$
\end{tabular}

\begin{tabular}{lll|l|l|l}
$3,731,510$ & $3,751,315$ & $4,575,504$ & $5,124,597$ & $5,897,219$
\end{tabular}

\begin{tabular}{l|l|l|l|l}
$3,290,161$ & $3,320,196$ & $3,620,203$ & $3,338,386$ & $3,434,557$
\end{tabular}

\begin{tabular}{ll|l|l|l|l}
$3,060,841$ & $3,215,245$ & $3,309,336$ & $3,640,504$ & $4,283,267$
\end{tabular}

\begin{tabular}{l|l|l|l|l}
$2,963,903$ & $2,747,719$ & $3,020,863$ & $3,149,454$ & $3,256,185$
\end{tabular}

\begin{tabular}{l|l|l|l|l|l}
$2,989,557$ & $2,990,022$ & $3,524,938$ & $3,058,106$ & $2,717,237$
\end{tabular}

\begin{tabular}{ll|l|l|l|l}
$2,605,669$ & $1,880,449$ & $2,886,676$ & $3,335,718$ & $3,324,292$
\end{tabular}

\begin{tabular}{l|l|l|l|l}
$2,378,239$ & $2,295,792$ & $1,918,079$ & $1,912,895$ & $1,982,833$
\end{tabular}

\begin{tabular}{l|l|l|l|l}
$1,949,780$ & $2,268,846$ & $2,231,225$ & $2,150,159$ & $2,113,206$
\end{tabular}

\begin{tabular}{ll|l|l|l|l}
$1,579,615$ & $1,334,747$ & $1,578,447$ & $1,645,923$ & $1,655,385$
\end{tabular}

\begin{tabular}{l|l|l|l|l}
$1,472,878$ & $1,647,541$ & $1,877,161$ & $1,828,389$ & $1,980,836$
\end{tabular}

\begin{tabular}{ll|l|l|l}
$1,110,343$ & $1,065,376$ & $1,115,422$ & 995,099 & $1,026,304$
\end{tabular}

\begin{tabular}{l|l|l|l|l}
$1,081,305$ & $1,446,440$ & $1,138,782$ & $1,398,257$ & $1,381,738$
\end{tabular}

\begin{tabular}{ll|l|l|l}
$1,045,590$ & 978,145 & 982,782 & $1,005,797$ & $1,447,429$
\end{tabular}

\begin{tabular}{l|l|l|l|l}
542,358 & 536,096 & 607,121 & 505,997 & 489,595
\end{tabular}

\begin{tabular}{ll|l|l|l}
530,635 & 250,477 & 276,873 & 247,354 & 204,737
\end{tabular}

\begin{tabular}{lll|l|l|}
438,848 & 320,602 & 318,717 & 334,128 & 410,797
\end{tabular}

\begin{tabular}{ll|l|l|l}
462,148 & 397,734 & 311,157 & 296,495 & 329,813
\end{tabular}

\begin{tabular}{l|l|l|l|l}
409,384 & 393,082 & 472,082 & 426,120 & 564,572
\end{tabular}

\begin{tabular}{ll|l|l|l}
$\mathbf{4} 07,665$ & 519,119 & 614,917 & 514,453 & 556,240
\end{tabular}

\begin{tabular}{ll|l|l|l}
368,763 & 323,684 & 314,417 & 327,567 & 327,895
\end{tabular}

\begin{tabular}{l|l|l|l|l}
280,343 & 284,916 & 288,859 & 323,118 & 412,026
\end{tabular}

\begin{tabular}{ll|l|l|l}
279,709 & 337,111 & 446,709 & 364,403 & 364,508
\end{tabular}

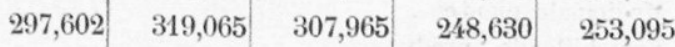

\begin{tabular}{ll|l|l|l}
147,902 & 171,261 & 182,243 & 218,183 & 241,080
\end{tabular}

\begin{tabular}{ll|l|l|l}
$2,208,658$ & $2,400,360$ & $3,886,020$ & $3,557,596$ & $2,108,450$
\end{tabular}

$91,029,32795,021,68296,545,92893,085,63799,196,638$ 
Overzicht van den Uitroer van Rio de Jaxerro.

\begin{tabular}{|c|c|c|c|c|c|c|}
\hline UITVOER VAN : & $\begin{array}{l}\text { 1878-z9 } \\
\text { in milreis. }\end{array}$ & $\begin{array}{l}\text { 1879-80 } \\
\text { in milreis. }\end{array}$ & $\begin{array}{l}1880-81 \\
\text { in milreis. }\end{array}$ & $\begin{array}{l}\text { 1881-52 } \\
\text { in milreis. }\end{array}$ & $\begin{array}{l}\mathbf{1 8 8 2 - 8 3} \\
\text { in milreis. }\end{array}$ & TOELICHTING. \\
\hline $\begin{array}{l}\text { 1. Vereenigde Staten van } \mathrm{N} . \text {-Amerika } \\
\text { 2. Frankrijk. } \\
\text { 3. Groot-Brittannië } \\
\text { 4. Duitschland }\end{array}$ & $\begin{array}{r}57,805,380 \\
12,999,898 \\
12,731,749 \\
10,087,520 \\
3,973,808 \\
3,362,613 \\
1,254,918 \\
1,259,059 \\
- \\
1,458,113 \\
572,887 \\
228,292 \\
97,155 \\
96,338 \\
84,430 \\
34,403 \\
- \\
- \\
14,637 \\
86 \\
106,061,286\end{array}$ & $\begin{array}{r}58,867,300 \\
9,161,033 \\
18,806,902 \\
11,098,028 \\
2,411,364 \\
4.522,365 \\
1,996,032 \\
945,490 \\
1,562,997 \\
275,069 \\
569,160 \\
180,841 \\
37,680 \\
391,144 \\
- \\
5,506 \\
657,612 \\
14,370 \\
18,221 \\
568,797 \\
112,089,911\end{array}$ & $\begin{array}{r}55,648,979 \\
17,111,018 \\
11,006,995 \\
10,873,686 \\
6,259,792 \\
5,063,843 \\
2,523,288 \\
1,791,925 \\
2,185,868 \\
581,536 \\
672,708 \\
394,750 \\
44,764 \\
194,783 \\
2,671 \\
104,479 \\
770,708 \\
100 \\
100,470 \\
82 \\
15,332,445\end{array}$ & $\begin{array}{r}50,178,416 \\
9,035,093 \\
7,114,927 \\
10,309,960 \\
3,106,794 \\
2,341,145 \\
1,524,257 \\
1,305,462 \\
1,426,063 \\
166,127 \\
429,781 \\
102,760 \\
82,277 \\
415,699 \\
124,049 \\
7,658 \\
502,911 \\
168,398 \\
4,464 \\
69 \\
88,346,310\end{array}$ & 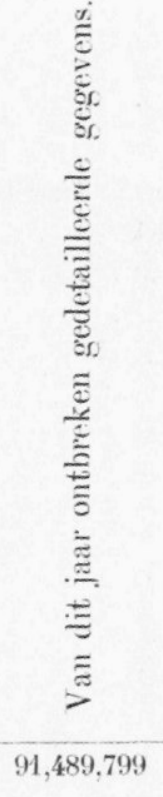 & $\begin{array}{l}\text { Samengesteld uit de } \\
\text { "Mappas Estatishicos do } \\
\text { Commerrio e Navigaçāo } \\
\text { do porto do Rio de Ja- } \\
\text { neiro, organisados e pu- } \\
\text { blic xdos pela Alfandega } \\
\text { com autorisaçäo de S. } \\
\text { E.x. O Sen. Ministro } \\
\text { da Fazenda" 1878-79 } \\
\text { tot 1881-82. }\end{array}$ \\
\hline
\end{tabular}


Overzicht van den Invoer van Rio DE $\boldsymbol{J}_{\text {ANEIro. }}$

\begin{tabular}{|c|c|c|c|c|c|c|c|c|c|c|}
\hline TNVOER V & vAN : & & & & $\begin{array}{l}1888-89 \\
\text { in milreis. }\end{array}$ & $\begin{array}{l}\text { 1879-80 } \\
\text { in milreis. }\end{array}$ & $\begin{array}{l}1880-81 \\
\text { in milreis. }\end{array}$ & $\begin{array}{l}\text { 1881-82 } \\
\text { in milreis. }\end{array}$ & $\begin{array}{l}\text { 1882-83 } \\
\text { in milreis. }\end{array}$ & TOELICHTING. \\
\hline 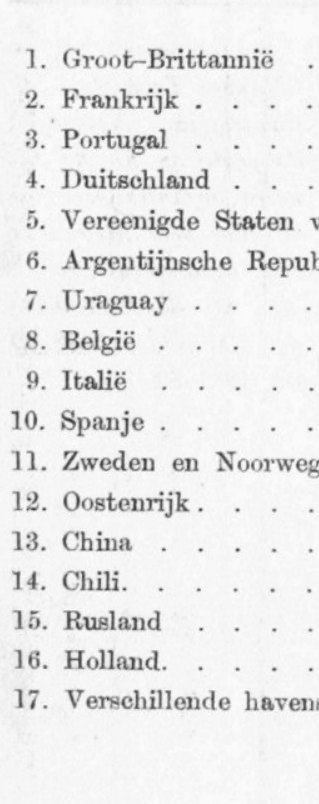 & 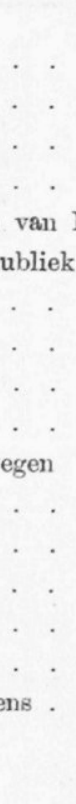 & 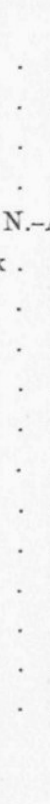 & 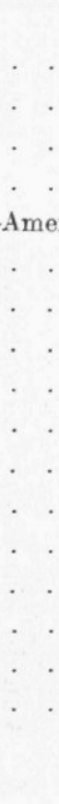 & 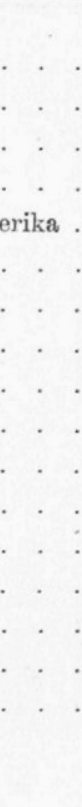 & $\begin{array}{r}a . \\
35,132,718 \\
16,984,837 \\
5,753,981 \\
8,093,137 \\
7,484,354 \\
5,516,182 \\
4,420,244 \\
5,231,629 \\
909,777 \\
804,051 \\
150,638 \\
150,987 \\
245,539 \\
35,460 \\
38,079 \\
36,998 \\
40,716\end{array}$ & $\begin{array}{r}a . \\
38,135,439 \\
16,141,122 \\
6,527,611 \\
8,535,907 \\
8,160,769 \\
4,043,939 \\
6,015,536 \\
4,730,556 \\
882,130 \\
549,923 \\
285,010 \\
72,038 \\
662,606 \\
126,927 \\
592 \\
146,031 \\
5,546\end{array}$ & \begin{tabular}{r}
\multicolumn{1}{c}{$b}$. \\
$37,737,108$ \\
$17,499,921$ \\
$6,537,204$ \\
$8,221,897$ \\
$8,264,919$ \\
$3,924,649$ \\
$7,520,146$ \\
$5,089,052$ \\
727,434 \\
205,797 \\
19,077 \\
78,988 \\
286,679 \\
196,042 \\
75,452 \\
152,340 \\
9,223
\end{tabular} & \begin{tabular}{r}
\multicolumn{1}{c}{$b}$. \\
$37,615,875$ \\
$16,697,658$ \\
$6,547,997$ \\
$8,332,510$ \\
$8,085,191$ \\
$3,522,684$ \\
$5,599,723$ \\
$4,370,494$ \\
754,097 \\
403,666 \\
242,921 \\
147,062 \\
7,658 \\
552,002 \\
48,533 \\
131,629 \\
25,937
\end{tabular} & 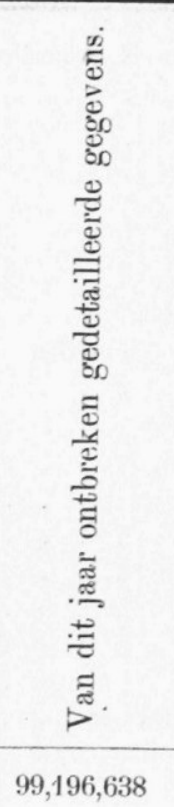 & $\begin{array}{l}\text { a. Volgens de "Re- } \\
\text { latorio da Associaçāo } \\
\text { Commercial do Rio de } \\
\text { Janeiro 1881. } \\
\text { b. Volgens de "Mappas } \\
\text { Estatislicos do Commer- } \\
\text { cio e Navigaçāo do porto } \\
\text { do Rio de Jan. 1880-81 } \\
\text { tot 1881-82. }\end{array}$ \\
\hline
\end{tabular}


STAAT, aantoonende welke rechten bij den Uitroer en Invoer van producten en goederen worden geheven.

Uitvoerrechten, geheven in het dienstjaar 1881-82.

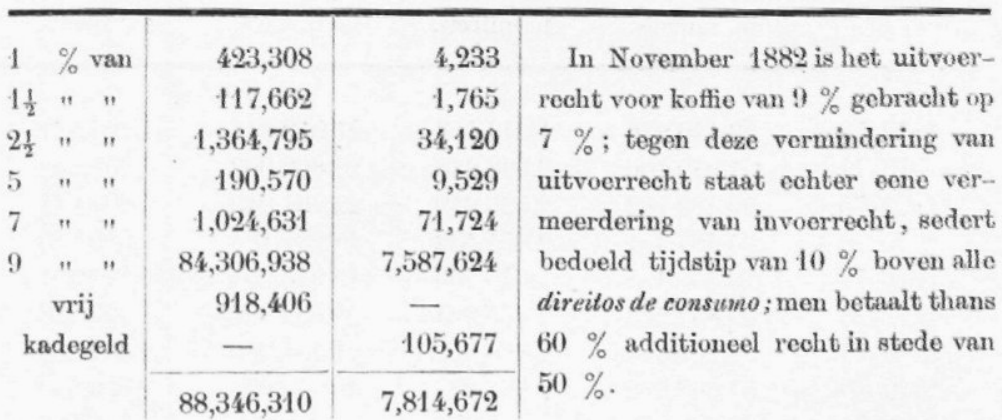

Invoerrechten, geheven in het dieustjaar 1881-82.

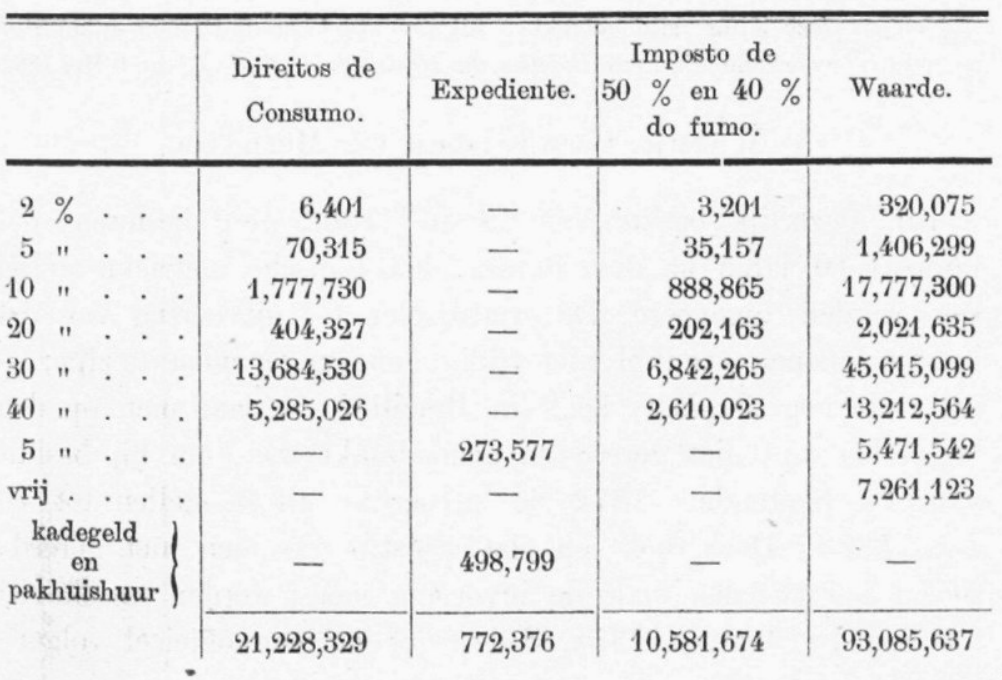


STAAT aantoonende de waarden van den In- en Uitvoer te Santos, en de rechten daarvan geheven, gedurende de laatste 10 dienstjaren.

\begin{tabular}{c|c|c|c|c}
\hline & $\begin{array}{c}\text { UITvokR } \\
\text { in milreis. }\end{array}$ & $\begin{array}{c}\text { Uitvoerrechten } \\
\text { in milreis. }\end{array}$ & $\begin{array}{c}\text { INvoER } \\
\text { in milreis. }\end{array}$ & $\begin{array}{c}\text { Invoerrechten } \\
\text { in milreis. }\end{array}$ \\
\hline & $a$. & $b$. & $c$. & $d$. \\
$1872-73$ & $23,149,276$ & $1,943,153$ & $21,919,911$ & $1,104,229$ \\
$1873-74$ & $31,949,106$ & $2,688,248$ & $22,860,003$ & $1,284,903$ \\
$1874-75$ & $29,489,782$ & $2,526,249$ & $22,761,245$ & $1,694,641$ \\
$1875-76$ & $25,487,451$ & $2.051,532$ & $20,291,134$ & $1,650,979$ \\
$1876-77$ & $20,556,132$ & $1,610,703$ & $19,913,234$ & $1,471,751$ \\
$1877-78$ & $29,887,258$ & $2,485,924$ & $19,682,926$ & $1,777,016$ \\
$1878-79$ & $32,601,300$ & $2,828,558$ & $21,461,060$ & $2,267,280$ \\
$1879-80$ & $31,208,992$ & $2,707,237$ & $20,449,072$ & $2,690,659$ \\
$1880-81$ & $30,330,675$ & $2,664,273$ & - & $3,110,792$ \\
$1881-82$ & $32,807,271$ & $2,882,277$ & - & $3,109,024$
\end{tabular}

a. Deze uitvoer-getallen zijn getrokken uit de Relatorio da Associaçāo Commercial do Santos 1882 en 1883. De voornaamste uilvoer-artikelen zijn: koffie, katoen, tabak en spek (toucinho).

c. Deze gegevens zijn genomen uit de Relatorin van do, provincie S. Paulo 1881.

$b$ en $d$. Deze cijfers zijn getrokken uit den staat van de Douane-inkomsten te Santos, voorkomende in de Boletim da Alfandega do R. de J. van 9 Mei 1883.

b. Maten, Gewichten en Munten.

Bij keizerlijk besluit van 26 Juli 1862 werd besloten, dat bimnen 10 jaren na dien datum, het fransche metrieke stelsel zou worden ingevoerd. De maatregelen ter uitvoering van dat besluit schenen evenwel niet tijdig genoeg genomen te zijn, iets wat nog al plaats heeft in Brazilië, - daar men op den bepaalden tijd niet gereed en genoodzaakt was, om bij besluit van 18 September 1872 de invoering uit te stellen tot 10 Juli 1873. Doch ook op dat tijdstip was men niet gereed, zoodat ten tweeden male de invoering moest worden verschoven tot den len Januari 1874. Sedert rekent men officieel volgens het nieuwe systeem.

Gelijk evenwel te verwachten was, is ook thans nog, vooral in de binnenlanden, het oude stelsel nog niet geheel verlaten. De koffie bijv. wordt nog altijd bij arroba verkocht, ofschoon de verkooprekeningen en noteeringen per 10 kilogrammen berekend worden.

De oude maten en gewichten, die nog veel gebruikt worden, zijn de volgende: 
1 arroba $=14,688$ kilos

1 alqueire $=36,27$ liters; in de binnenlanden heeft men echter alqueires van 40,45 en 50 liters.

Als vlaktemaat gebruikt men verscheidene soorten van alqueires als:

1 alqueire planta de milho $=27225 \square$ Meters
1 alqueire paulista
1 alqueire géometrico

In den vroegeren chaos waarin het muntsysteem in Brazilië verkeerde, is sedert 1870 meer regeling gekomen. Instede vau de verschillende portugeesche en vreemde munten, heeft men thans voor het gansche rijk een eigen muntstelsel. De munteenheid is de real (enkelvoud van reis) welke feitelijk niet bestrat. Men rekent bij reis. Het koper, nickel en zilvergeld worlt uitsluitend beschouwd als pasmunt, en is niterst schaars. Alles wordt betaald met papiergeld.

De pasmunt bestaat nit:

a. munten van koper, die zeer zeldzaam zijn, als stukken van: 10 reis (diz-reis); 20 reis (vintêm); 40 reis.

b. munten van nickel: 50 reis (deze munt is gemaakt, maar niet in omloop gebracht); 100 reis; 200 reis.

c. munten van zilver: 200 reis (zeer zeldzaam); 500 reis; 1000 reis (milreis); 2000 reis.

Brazilië heeft ook goudgeld volgens de wet van $184.7 \mathrm{nl}$. 20 milreis-stukken; 10 milreis-stukken en 5 milreis-stukken. Zijn de twee eerstbedoelde muntstukken schaars, de stukken van 5 milreis zij̣n bijna geheel uit de circulatie. In het dagelịkksch leven kent men ze weinig, zij worden dan ook, evenals de vreemde gouden en zilveren munten, als handelswaar beschouwd, en als zoodanig volgens koers verhandeld.

Het rijkst is Brazilië aan papiergeld, dat sedert 1819 een gedwongen koers heeft. Men heeft Staats- en Bank- (van de Banco do Brazil) papier van de volgende hoeveelheden: 500 reis, en $1,2,5,10,20,25,30,50,100,200$ en 500 milreis. Men kan rekenen dat 1 milreis $=f 1.20$ is.

In de binnenlanden, vooral onder de negers en den kleinen man rekent men nog veel met tostaōes, crusados en patacas; alsdan zegt men. 1 tostāo voor 100 reis; 2 tostaōes voor 200 ; 3 tostaōes voor $300 ; 1$ crusado voor 4,$00 ; 5$ tostaōes voor 500 ; 6 tostaōes voor $600 ; 7$ tostaōes voor $700 ; 2$ crusados voor 800 reis enz. 
De berekening met patacas is niet zoo gemakkelijk, aangezien 1 pataca $=320$ reis, en men spreekt van een halve en anderhalve patacas

Op het gezicht is het moeilijk voor een vreemdeling, om de munten en het papiergeld van elkander te onderscheiden.

De nickelstukken van 100 en 200 reis bijv. zijn zóó groot (even groot en grooter dan onze guldenstukken) en hebben op het gezicht zóóveel ovreenkomst met de zilverstukken van 1 en 2 milreis dat men zich vaak vergist. Op den tast zijn de zilver- van de nickelnunten te onderscheiden door den gekartelden rand van eerstbedoelde stukken.

Het papiergeld, - dat gelijk men kan nagaan wegens het dagelijksch gebruik vrij onooglijk is, - herkent men in den regel aan de kleur en de verschillende grootte of breedte.

Gelijk zeer begrijpelijk is, geeft die overvloed van papiergeld met gedwongen koers aanleiding tot koersfluctuatiën, welke een grooten invloed uitoefenen op den handel in het algemeen en op den koffiehandel in het bizonder, aangezien zelfs NoordAmerika zijn schuld betaalt met wissels op Londen en Liverpool.

Daar dus de koers op Engeland overwegend is op den omzet, geef ik hierbij een diagram aantoonende de koersfluctuatiën op de markt van Rio gedurende de laatste 33 jaren. 
DLAGRAM, aantoonende de koersfluctuatiën op de markt van Rio DE JANEIRo, sedert het jaar 1851.

De koersen zijn aangeduid door de horizontale lijnen, de jaren door de ruimten tusschen de verticale lijnen.

De pari-koers van de Milreis 27 d. zijnde, is die lijn dikker getrokken dan de andere.

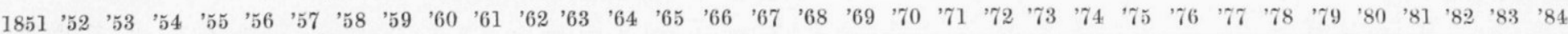

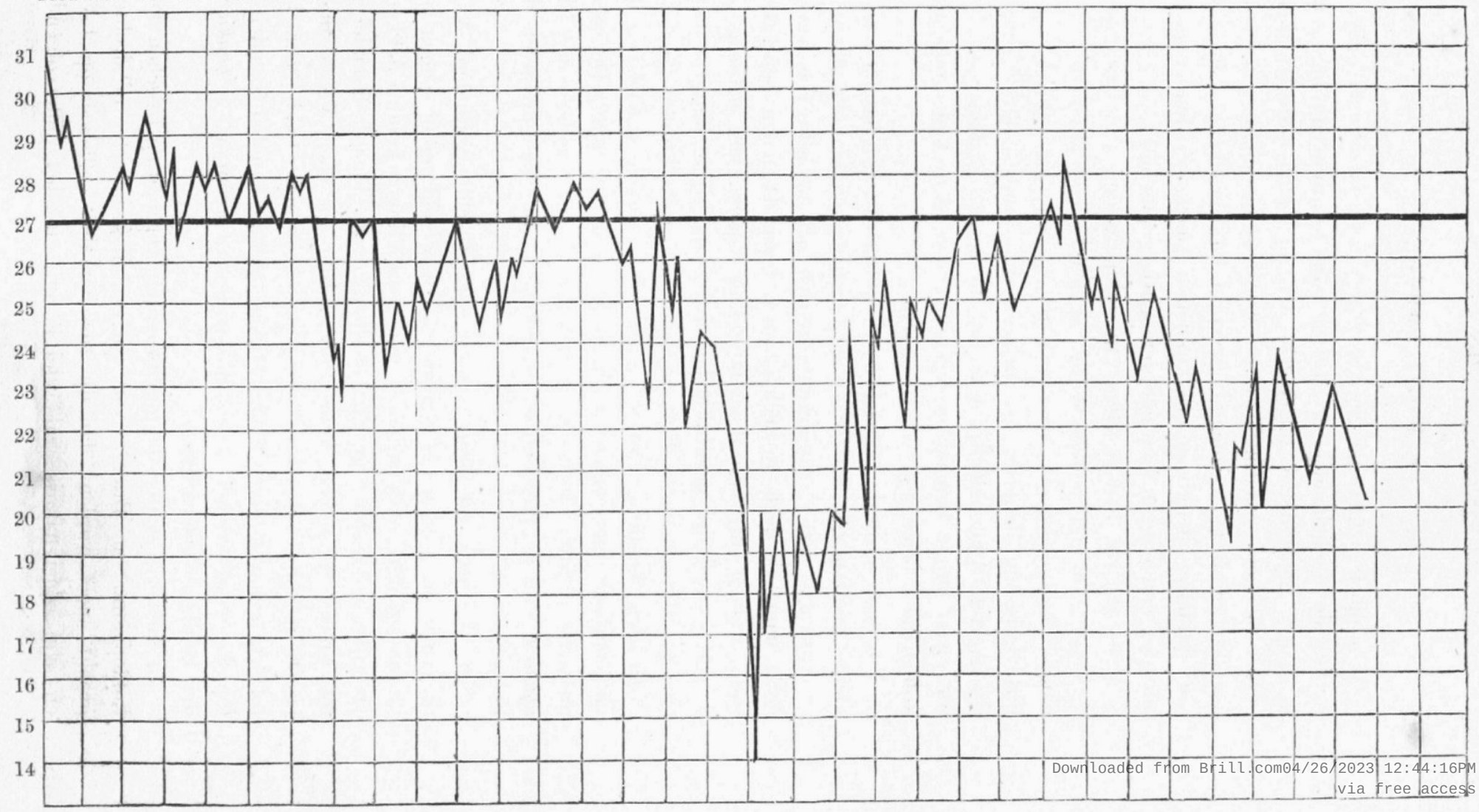


c. Koffiehandel.

Men moet ooggetuige geweest zijn van de ontzettende drukte, welke de koffiehandel in Rio en Santos teweegbrengt, de koortsige gejaagdheid opgemerkt en de ongehoorde snelheid gezien hebben, waarmede alles wordt afgehandeld, vervoerd, ontzakt, gestort, vermengd, verzakt en afgescheept, om zich een duidelijk denkbeeld te kunnen vormen van den enormen omvang van dat in waarheid reusachtig "Geschäft".

Met aandacht heb ik alles van nabij gezien, alles nagegaan, dagen en weken achtereen de verschillende phasen van dien handel bestudeerd en, om zoo te zeggen, in zijne kleinste bizonderheden bespied; - in één woord mij, zooveel dit in zoo korten tijd mogelijk was, op de hoogte gesteld van alles wat naar mịne bescheiden meening, voor den Nederlandschen koffiehandel belangrijk was te weten.

Mogen er al in de volgende beschrijuing van dien handel eenige kleine leemten zijn aan te vullen, men wijte de onvolkomenheid er van niet aan 's rapporteurs goeden wil om alles zoo nauwgezet mogelijk mede te deelen, maar bepaald aan den beperkten tijj, welken hij aan die studie kon wijgden, met het oog op de vele en velerlei moeilijkheden waarmede hịj te kampen harl, om aan zijn missie in haar ganschen omvang te kunnen voldoen.

In den beginne dreven verreweg de meeste fazendeiros de koffiecultuur met eigen middelen op hunne gronden. De commissarios waren toen in werkelijkheid niet anders dan de agenten van de fazendeiros, bemiddelaars tusschen dezen en de koopers.

In de laatste 20 jaren is die toestand echter veranderd. Van lieverlede begonnen de fazendeiros meer geld op te nemen bịj humne agenten, dan zij door koffie-toezendingen konden dekken. De rijke inkomsten van den landbouw verleidden de fazendeiros tot groote uitgaven, voor huishouding en spel. Vooral deze laatste hartstocht heeft in ruime mate het zijne er toe bijgebracht tot den tegenwoordigen af hankelijken toestand van den fazendeiro. Op die wijze werden de commissarios van agenten, de bankiers der landbouwondernemers.

In hoeverre echter de tegenwoordige verhouding tusschen den koffieplanter in Brazilië en zijnn commissario beter of slechter geacht moet worden, dan die tusschen den koffieboer op Java en zijn consignataris, zal, vlei ik mij, uit het ondervolgende 
gemakkelijk zijn na te gaan en af te leiden. Voor een jaar of 5 geleden kostte het den fazendeiro niet de minste moeite om geld op te nemen tot exploitatie, verbetering en uitbreiding van zijne onderneming of fazenda. Zoo hị geld noodig had, wendde hị zich tot den commissario, die niet het minste bezwaar maakte om het gevraagde voor te schieten, zonder andere garantie dan een eenvoudig reçu, en tegen de belofte dat het product aan hem ten verkoop zoude worden geconsigneerd. Slechts voor het geval dat de gevraagde som boven de 20 à 25 contos ging, eischte de commissario promessen op 4 maanden (in Rio zelden gelijk in Santos op 6,12 en 18 maanden), welk cultuurpapier door den commissario geëndosseerd, tegen bankrente bij deze of gene geldinstelling kon worden te gelde gemaakt. Gewoonlijk berekent de commissario 12 pCt. 's jaars over die voorschotten, welke rente ook op rekening-courant wordt vergoed.

Naar den staat van den geldopnemer werden die promessen dan of bij vervaldag geprolongeerd, of op de betaling er van aangedrongen. In den regel gebeurt het eerste, en mij zijn commissarios genoemd, die op deze wijze meer dan 1000 contos of 12 tomnen gouds uitstaande hebben, op slechts een drietal fazendeiros. Daaruit kan men opmaken dat, om thans als commissario te kumnen optreden, men over een zeer aanzienlijk kapitaal moet kunnen beschikken. Daar zijn dan ook commissarios die zaken doen met een eigen kapitaal van 300 tot 2000 contos. Zij die met minder eigen middelen optreden, en daarom hun cultuurpapier steeds bij de Banco do Brazil moeten disconteeren, worden door de rijke commissarios onder den spotnaam van commiezen van de Bank aangeduid.

Zelden zijn de commissarios tevens fazendeiros of omgekeerd. Men heeft ze echter; o. a. de firma's: Friburgo \& filhos en Araujo Maia Irmāo in Rio, die hoofdzakelijk eigen product verkoopen en die hunner vrienden. De leden van eerstgenoemde firma, de viscondes de $\mathrm{S}$. Clemente en de Nova-Friburgo kunnen met recht aanspraak maken op den titel van koffieprinsen, met een zuiver inkomen alléén van humne uitgestrekte fazendas van gemiddeld 727,000 gulden 's jaars!

Aan die groote gemakkelijkheid om fondsen voor zijn fazenda te krijgen is sedert een einde gekomen. Was het nog geen vijf jaren geleden van den kant van den commissario nog, -

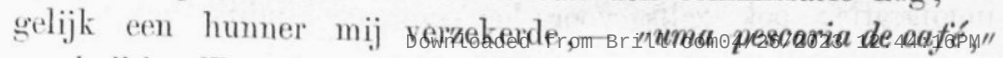
te Volgr. IX. 
een angelen naar een fazendeiro, die het product wilde consigneeren, - thans begint men aan eene mogelijke liquidatie te denken, en worden de koorden der beurs meer en meer toegehaald. Thans zal het zoo licht niet meer gebeuren, dat een fazendeiro, ontevreden zijnde op zijn geldschieter, dadelijk een ander kan krijgen, die niet alleen de achterstallige schuld aanzuivert, maar den koffieboer nog uitgeleide doet, met een dankbaar: "welverplicht."

De crisis in alle geldzaken, welke men thans in Brazilië te gemoet gaat of, juister uitgedrukt, waarin men reeds getreden is, doet iedereen voor het ergste vreezen.

Reeds is de Banco do Brazil sedert het nieuwe jaar 1884 genoodzaakt tegen 10 en $11 \%$ te disconteeren, en twee soliede endossanten te eischen, in stede van één, voor alle promessen van fazendeiros, terwijl zij 9 tot $10 \%$ vordert voor beleeningen op effecten en waarden. En zulks wordt dan nog beschouwd als eene concessie, waartoe men schoorvoetend besluit, aangezien het grootste gedeelte van het Bankkapitaal ter beschikking der Regeering gesteld moest worden.

De naderende oplossing ran de arbeiderskwestie of liever de onvermijdelijke doorhakking van dien niet te ontwarren knoop; de veldwinnende emancipatiegeest en de abolitionistische beweging, welke met den dag in ernst en omvang toeneemt; de twee elkander opvolgende geringe koffieoogsten 1883-84 en 1884-85; de mislukte poging om door de chineesche immigratie in de eerste behoeften van den landbouw te voorzien, de moeielijkheid om Europeesche werkkrachten in voldoende mate naar het land te trekken; ziedaar de redenen die tot dien crisis hebben geleid, en hem elk jaar jammerlijker in zijne gevolgen zal doen wezen.

De toestand waarin de fazendeiro thans over het algemeen verkeert, is bedroevend en geeft naar mijne meening al zéér weinig hoop op beterschap. Eenige ruime oogsten, gepaard aan hoogere marktprijzen, kunnen zijn naderenden val nog doen uitstellen of verzachten, dien geheel voorkomen of tegengaan, vermogen zij niet wegens het nijpend gebrek aan werkkrachten om de reeds te uitgestrekte aanplantingen behoorlijk te onderhouden en de oogsten af te werken.

Met leedwezen moet ik erkennen, dat ik ten deze mij niet kan scharen onder hen, die veel verwachten van de europeesche

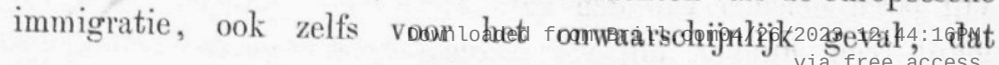


Brazilië 's jaars 200 à 250 duizend immigranten tot zich kan trekken.

Het tegenwoordig stelsel van vrijen arbeid, n.l. de contractueële kolonistenarbeid, kan de koffiecultuur als grande lavoura niet redden. Het stelsel mist mijns inziens allen vasten grond; want zoo men de basis, waarop alles rust, n.l. den slavenarbeid bij entginning en aanplant, wegdenkt, valt alles inéén.

Gelijk ik in het hoofdstuk "Koffiecultuur" nader zal aantoonen, zijn de kolonisten geen koffieplanters, maar uitsluitend koffieplukkers. Zij willen slechts eenige duizende vruchtdragende boomen per man onderhouden, - niet het derde gedeelte echter van wat een veldslaaf planten en onderhouden moet, - en dáárvan het product plukken; maar dat alles geschiedt met tegenzin en alléén omdat zij slechts op die voorwaarde gronden kunnen bekomen voor het aanplanten van levensmiddelen. Konden zij op andere voorwaarden gronden ter bebouwing krijgen, geen twijfel of zij zullen dáárop slechts die producten teelen, welke gemakkelijker zonder verdere bereiding kunnen worden te gelde gemaakt, gelijk maïs, boonen, aardappelen, mendioca en groenten. Dit werd mij niet door één, maar door meer kolonisten en oudkolonisten verzekerd.

Weinige fazendeiros, in de Santos-zōne, willen dit inzien, of ten minste er voor uitkomen. In Rio zijn echter de meeste commissarios en groothandelaren in koffie, die ik gesproken heb, van mijne meening; ook zij erkennen dat, zoolang de dagloonen zoo hoog zijn, en een europeesche immigrant in Brazilië met andere cultures dan koffie ruim in zijn onderhoud kan voorzien, hij deze cultuur nu juist niet zal beschouwen als de meest productieve en aangename.

Het is deze onzekere toestand van de grande lavoura, welke maakt dat men thans geen fondsen meer voor de koffieteelt beschikbaar heeft, dan tegen soliede garantie. Gewoonlijk wordt thans een notarieële acte vereischt, waarin, blijkens de twee contracten welke in mịn bezit zijn, de volgende voorwaarden zijn opgenomen :

1. dat de schuld zal betaald worden in vijf gelijke termijnen te beginnen met..... en vervolgens van jaar tot jaar tot....

2. dat over die schuld zal berekend worden (in het eerste contract) $5 \%$ en (in het tweede) $10 \%$ van af .... ; zullende de rente om het halfjaar worden afbetaald, te beginnen met...... 
3 dat de betaling zal geschieden ten kantore van den schuldeischer of geldschieter.

4. dat de schuldenaar voor het verschuldigde wissels zal afgeven betaalbaar op de bepaalde termijnen.

5. dat $1 \%$ boete verschuldigd zal wezen, zoo de betaling niet op tijd plaats vindt.

6. dat de schuldenaar aan den geldschieter zal consigneeren al de producten van zijn fazenda, en van het netto-provenu daarvan slechts zooveel zal opnemen als voor de landbouwuitgaven noodig geacht wordt, zullende hem op rekening-courant dezelfde rente worden vergoed, als die welke hij volgens het contract betalen moet.

7. dat de schuld in haar geheel opeischbaaar zal wezen : $\boldsymbol{a}$. bij niet betaling op den bepaalden dag; $b$. bij niet-nakoming der artikelen 4 en 6 of een er van; $c$. bij overlijden van den schuldenaar en $d$. bij aflossing van de $l^{\circ}$ hypotheek van de Banco do Brazil.

8. dat bij gerechtelijke vervolging door den schuldenaar als boete verschuldigd zal zijn $10 \%$ van de hoofdsom boven en behalve de gerechtskosten. Het domicilie is ter plaatse waar het contract gesloten wordt.

9. dat de geldschieter niet verplicht is, de gerechtelijke toewijzing van de fazenda aan te nemen, maar het recht zal hebben om zoo dikwijls veilingen te doen plaats vinden, telkens met eene korting van $10 \%$ van de geschatte waarde, als noodig zijn om tot den definitieven verkoop te geraken. Indien zich bij de verschillende veilingen geen bieder opdoet, heeft de geldschieter het recht zich zooveel goederen te zijner keuze te doen toewijzen als noodig is tot afdoening van schuld zonder benadeeling van het recht van den eersten hypotheekhouder.

[Met deze laatste bepaling heeft men het oog eerstens op de koffie welke op de fazenda aanwezig kan zijn, en ten andere op alles wat sedert het passeeren van de éérste hypotheek mocht zijn aangeschaft aan roerend of onroerend goed, bijv.: een stuk grond ter afronding van de onderneming.]

10. dat tot meerdere zekerheid tot afdoening der schuld op al de bij de Banco do Brazil belaste goederen van den schuldenaar bestaande uit ..... een tweede en speciale hypotheek zal worden gegeven ten behoeve van den geldschieter.

Dergelijke notarieële acten behoeven slechts geregistreerd

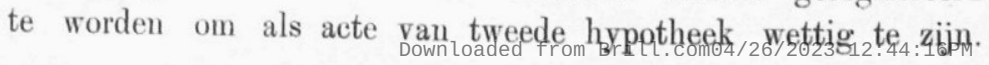


In Santos worden thans nog hoogst zelden consignatiecontracten gesloten. De commissarios schieten daar nog geld voor op wissels van 6,12 tot 18 maanden, die slechts voor den tijd van 4 maanden bij de Bank kunnen worden gedisconteerd. Bij uitzondering wordt een notariëel contract opgemaakt.

Wanneer een fazendeiro zóó ten achter is en niet wil of kan betalen, roept men de tusschenkomst van den advocaat in. Heeft deze genoeg verdiend, dan helpt hij den fazendeiro. en den commissario aan een compromis, bij welke gelegenheid de fazendeiro dan een accoord maakt om slechts 70 à 75 pC't. te betalen. Alsdan geeft hij als zekerheid een tweede hypotheek.

Zeer weinige fazendeiros zijn thans vrij, bijna allen hebben hunne ondernemingen bezwaard, hetzij bij particulieren, hetzij bịj banken en geldinstellingen.

Bij de Banco do Brazil, Banco Predial en de Banco de Credito real de S. Paulo alléén zijn, gelijk uit de hieronder volgende staten blijkt, 1039 fazendas verbonden, een waarde vertegenwoordigende van ruim 115 millioen milreis of 138 millioen gulden, en deze fazendas behooren nog tot de beste. 
RIO-Z̄̄NE.

STAA'T aantoonende hoeveel fazendas in elk district van de provincie Rio

\begin{tabular}{|c|c|c|c|c|c|c|c|}
\hline \multicolumn{5}{|c|}{ DISTRICTEN. } & $\frac{\begin{array}{c}\text { Aantal } \\
\text { fazendas. }\end{array}}{41}$ & $\begin{array}{c}\begin{array}{c}\text { Grootte der } \\
\text { fazendas }\end{array} \\
\text { in hectaren. } \\
23,568\end{array}$ & $\frac{\begin{array}{c}\text { Aantal } \\
\text { koffieboomen }\end{array}}{7,104,000}$ \\
\hline 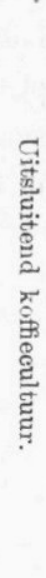 & $\begin{array}{l}\text { Cantagallo } \\
\text { Valença } \\
\text { Parahyba do Sul . } \\
\text { Barra Mansa } \\
\text { Rezende . } \\
\text { Santa Maria Magdaler } \\
\text { Nova Friburgo. } \\
\text { Pirahy . . . . . } \\
\text { Sapucaia.. } \\
\text { Barra de S. Joāo. } \\
\text { S. Antonio de Padua } \\
\text { Capivary. . . . } \\
\text { S. Joāo do Principe. }\end{array}$ & $\begin{array}{ll}\cdot & \cdot \\
\cdot & \cdot \\
\cdot & \cdot \\
\cdot & \cdot \\
\cdot & \cdot \\
\text { lena. } \\
\cdot & \cdot \\
\cdot & \cdot \\
\cdot & \cdot \\
\cdot & \cdot \\
& \cdot \\
\cdot & \cdot \\
. & \cdot\end{array}$ & . & $\begin{array}{l}. \\
. \\
. \\
. \\
\text {. }\end{array}$ & $\begin{array}{r}41 \\
33 \\
32 \\
23 \\
20 \\
13 \\
7 \\
7 \\
5 \\
4 \\
3 \\
2 \\
1\end{array}$ & $\begin{array}{r}23,568 \\
22,903 \\
19,359 \\
10,471 \\
16,602 \\
7,839 \\
3,970 \\
5,810 \\
2,223 \\
5,432 \\
1,096 \\
430 \\
242\end{array}$ & $\begin{array}{r}7,104,000 \\
9,469,000 \\
5,615,54: \\
3,345,000 \\
3,437,000 \\
1,942,000 \\
1,050,000 \\
3,460,000 \\
881,000 \\
570,000 \\
345,000 \\
400,000 \\
50,000\end{array}$ \\
\hline 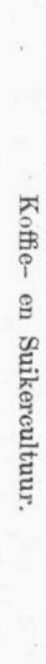 & 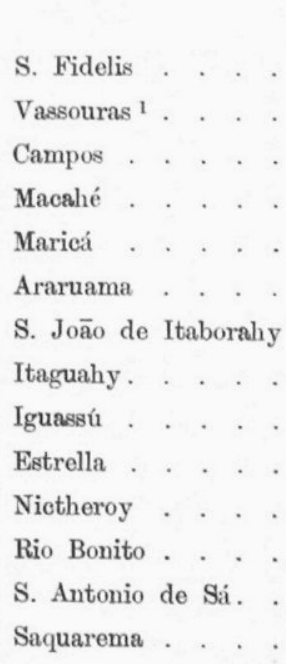 & $\begin{array}{ll}\cdot & \cdot \\
\cdot & \cdot \\
\cdot & \cdot \\
\cdot & \cdot \\
\cdot & \cdot \\
\cdot & \cdot \\
y & \cdot \\
\cdot & \cdot \\
\cdot & \cdot \\
\cdot & \cdot \\
\cdot & \cdot \\
\cdot & \cdot \\
\cdot & \cdot \\
\cdot & \cdot\end{array}$ & . & $\begin{array}{l}\text {. } \\
\text {. } \\
\text {. } \\
\text {. }\end{array}$ & $\begin{array}{r}191 \\
48 \\
44 \\
28 \\
10 \\
9 \\
6 \\
4 \\
3 \\
3 \\
1 \\
1 \\
1 \\
1 \\
1\end{array}$ & $\begin{array}{r}119,945 \\
43,568 \\
31,750 \\
28,805 \\
11,069 \\
3,867 \\
2,504 \\
1,676 \\
1,151 \\
923 \\
2,341 \\
953 \\
728 \\
1,065 \\
476\end{array}$ & 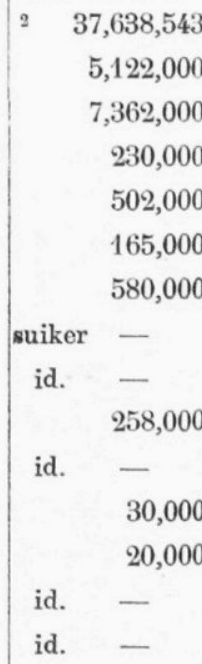 \\
\hline & & & & & 351 & 250,821 & $51,907,543$ \\
\hline
\end{tabular}

1 Behalve Vassouras, waar de suikercultuur (voor den export) weinig beteekent zijn de laatste 13 municipios in de Serra Abaixo gelegen. Sedert de laatste 10 jaren de koffiecultuur ook in het district S. Fidelis achteruitgaande wegens de koffiebladziekte.

2 Een slaaf heeft dus te onderhouden 3514 boomen. 
RIO-ZŌNE.

de Janeiro op den 30n Juni 1883 waren bezwaard bij de Banco do Brazil.

\begin{tabular}{|c|c|c|c|c|c|}
\hline $\begin{array}{l}\text { Aantal } \\
\text { slaven. }\end{array}$ & $\begin{array}{l}\text { Waarde der } \\
\text { slaven. } \\
\text { in milreis. }\end{array}$ & $\begin{array}{c}\text { Waarde van de } \\
\text { fazendas } \\
\text { in milreis. }\end{array}$ & $\begin{array}{c}\text { TOTAAL } \\
\text { in milreis. }\end{array}$ & $\begin{array}{c}\text { Verleende } \\
\text { voorschotten } \\
\text { in milreis. }\end{array}$ & $\begin{array}{c}\text { Restant } \\
\text { hypotheek op } \\
30 / 61883 \\
\text { in milreis. }\end{array}$ \\
\hline 1,995 & $2,433,750$ & $2,765,383$ & $5,199,133$ & $2,167,008$ & $1,491,491$ \\
\hline 2,893 & $3,460,100$ & $3,573,403$ & $7,033,503$ & $3,143,784$ & $2,392,464$ \\
\hline 1,468 & $1,744,350$ & $2,036,886$ & $3,781,236$ & $1,664,316$ & 976,665 \\
\hline 1,051 & $1,209,200$ & $1,254,962$ & $2,464,162$ & $1,088,380$ & 614,092 \\
\hline 926 & $1,056,550$ & $1,597,639$ & $2,654,189$ & $1,171,163$ & 691,968 \\
\hline 549 & 679,400 & 699,864 & $1,379,264$ & 615,500 & 406,475 \\
\hline 287 & 320,000 & 380,031 & 700,031 & 448,000 & 179,103 \\
\hline 844 & 829,550 & $1,019,158$ & $1,848,708$ & 808,814 & 621,479 \\
\hline 259 & 375,200 & 322,759 & 697,959 & 326,000 & 286,708 \\
\hline 296 & 279,250 & 193,790 & 473,040 & 191,000 & 65,954 \\
\hline 62 & 72,500 & 135,740 & 208,240 & 90,000 & 90,000 \\
\hline 54 & 45,400 & 108,068 & 153,468 & 60,000 & 32,525 \\
\hline 28 & 25,700 & 32,465 & 58,165 & 25,000 & 11,494 \\
\hline$=10,712$ & $12,530,950$ & $14,120,148$ & $26,651,098$ & $11,798,965$ & $7,860,418$ \\
\hline 1,940 & $2,225,400$ & $2,524,700$ & $4,750,100$ & $1,986,249$ & $1,427,901$ \\
\hline 2,853 & $3,238,250$ & $3,677,958$ & $6,916,208$ & $2,878,380$ & $1,857,121$ \\
\hline 1,746 & $1,866,600$ & $1,755,720$ & $3,622,320$ & $1,495,000$ & $1,039,802$ \\
\hline 396 & 470,500 & 516,485 & 986,985 & 450,000 & 328,214 \\
\hline 374 & 377,400 & 305,720 & 683,120 & 233,000 & 148,426 \\
\hline 248 & 240,100 & 211,906 & 452,006 & 226,005 & 61,233 \\
\hline 126 & 130,200 & 144,251 & 274,451 & 160,000 & 91,039 \\
\hline 110 & 132,600 & 81,938 & 214,538 & 92,000 & 55,939 \\
\hline 162 & 200,000 & 124,958 & 324,958 & 147,600 & 119,911 \\
\hline 10 & 11,000 & 21,750 & 32,750 & 10,000 & 1,500 \\
\hline 65 & 67,800 & 57,145 & 124,945 & 40,000 & 26,471 \\
\hline 56 & 67,600 & 40,340 & 107,940 & 35,000 & 19,650 \\
\hline 26 & 25,200 & 30,040 & 55,240 & 25,000 & 12,258 \\
\hline 58 & 61,400 & 55,631 & 117,031 & 50,000 & 35,083 \\
\hline 18,882 & $21,645,000$ & $23,668,690$ & $45,313,690$ & $19,627,199$ & $13,084,966$ \\
\hline
\end{tabular}




\section{RIO-ZŌNE.}

STAAT' aantoonende hoeveel fazendas in elk district van de tot de Santo en S. Paulo op den 30n Juni 1883

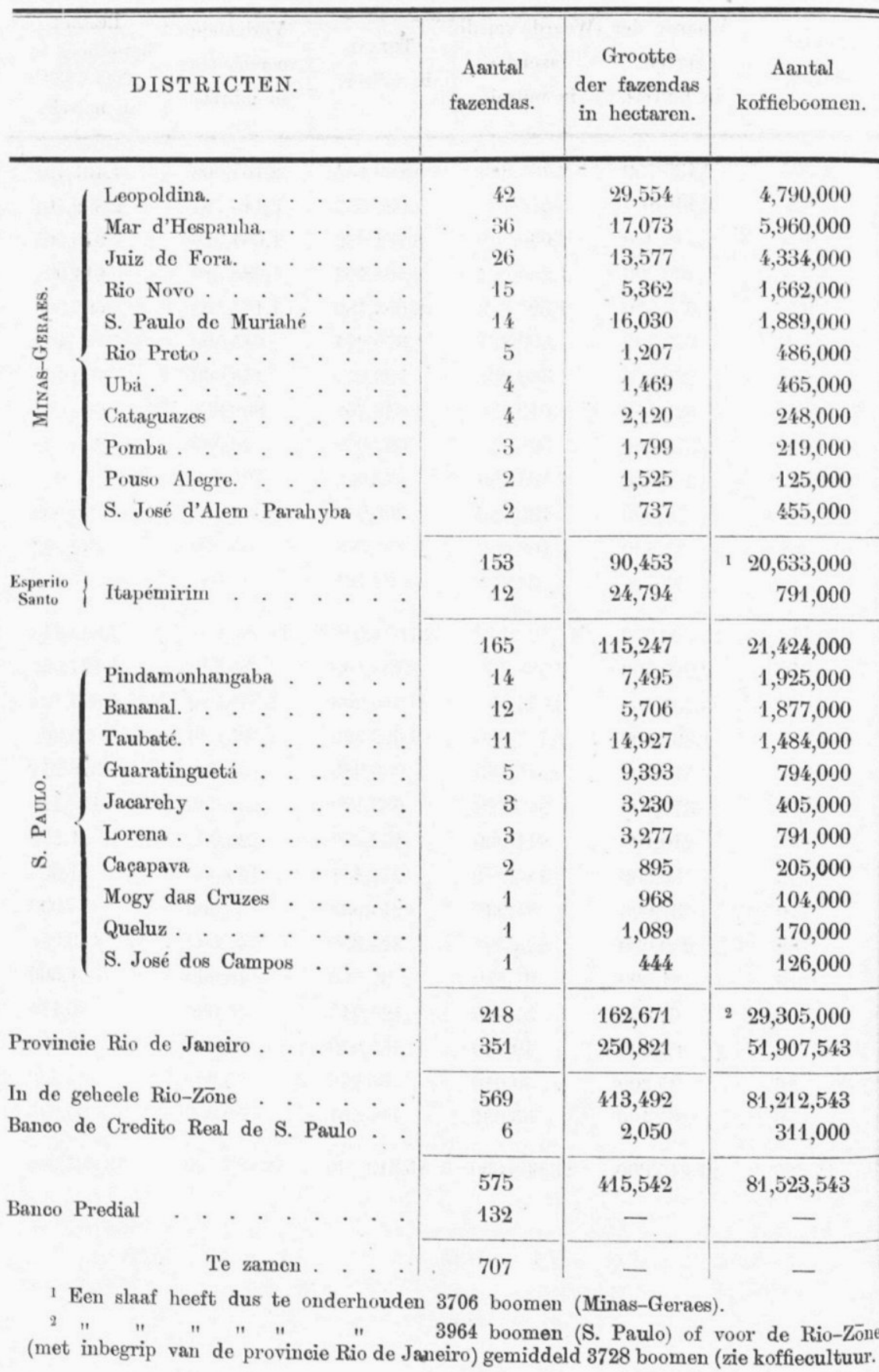




\section{RIO-ZŌNE.}

Rio-Zōne behoorende deelen van de provinciën Minas-Geraes, Espirito waren bezwaard bij de Banco do Brazil.

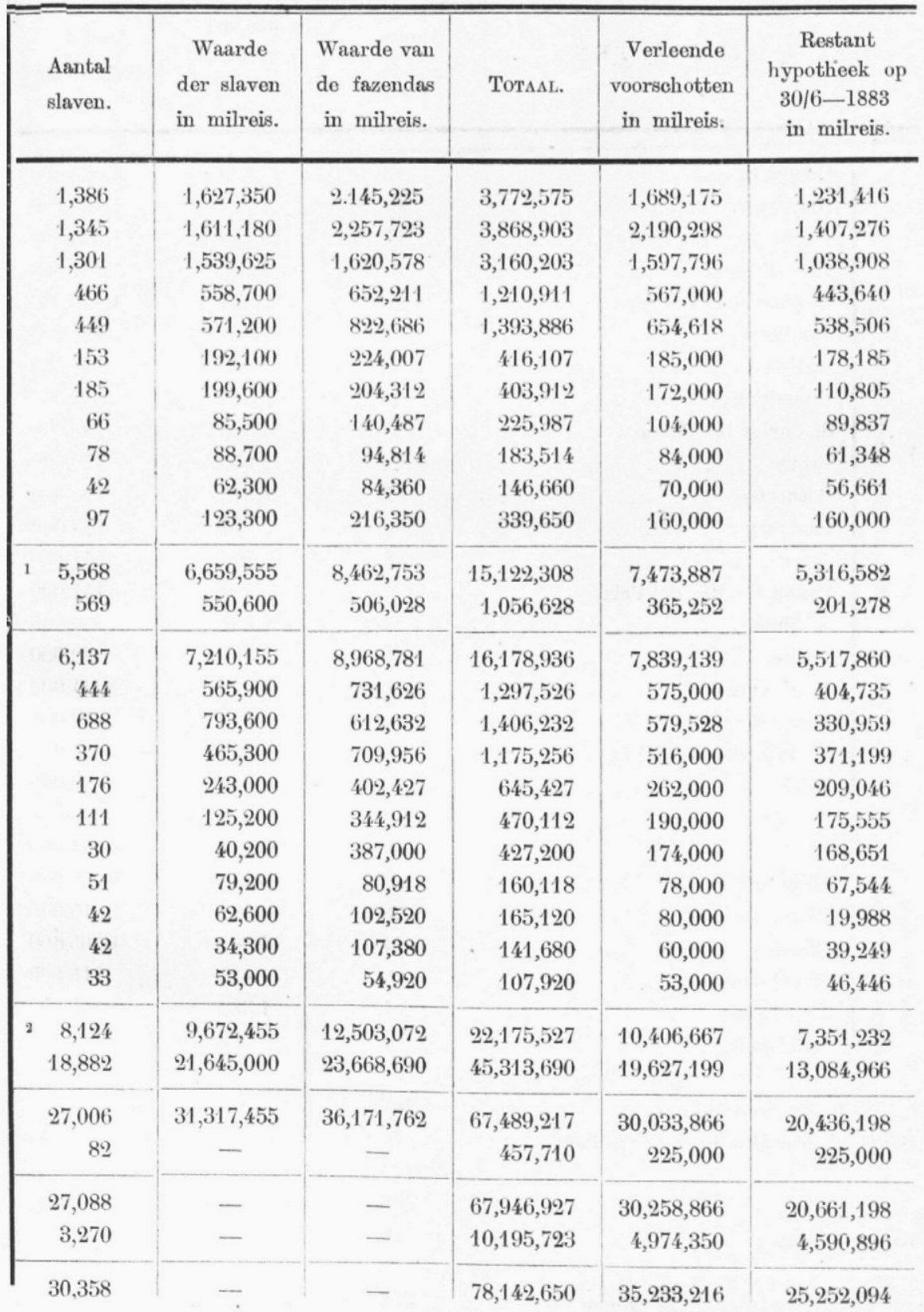




\section{SANTOS-ZŌNE.}

STAAT aantoonende hoeveel fazendas in elk district van de provincie

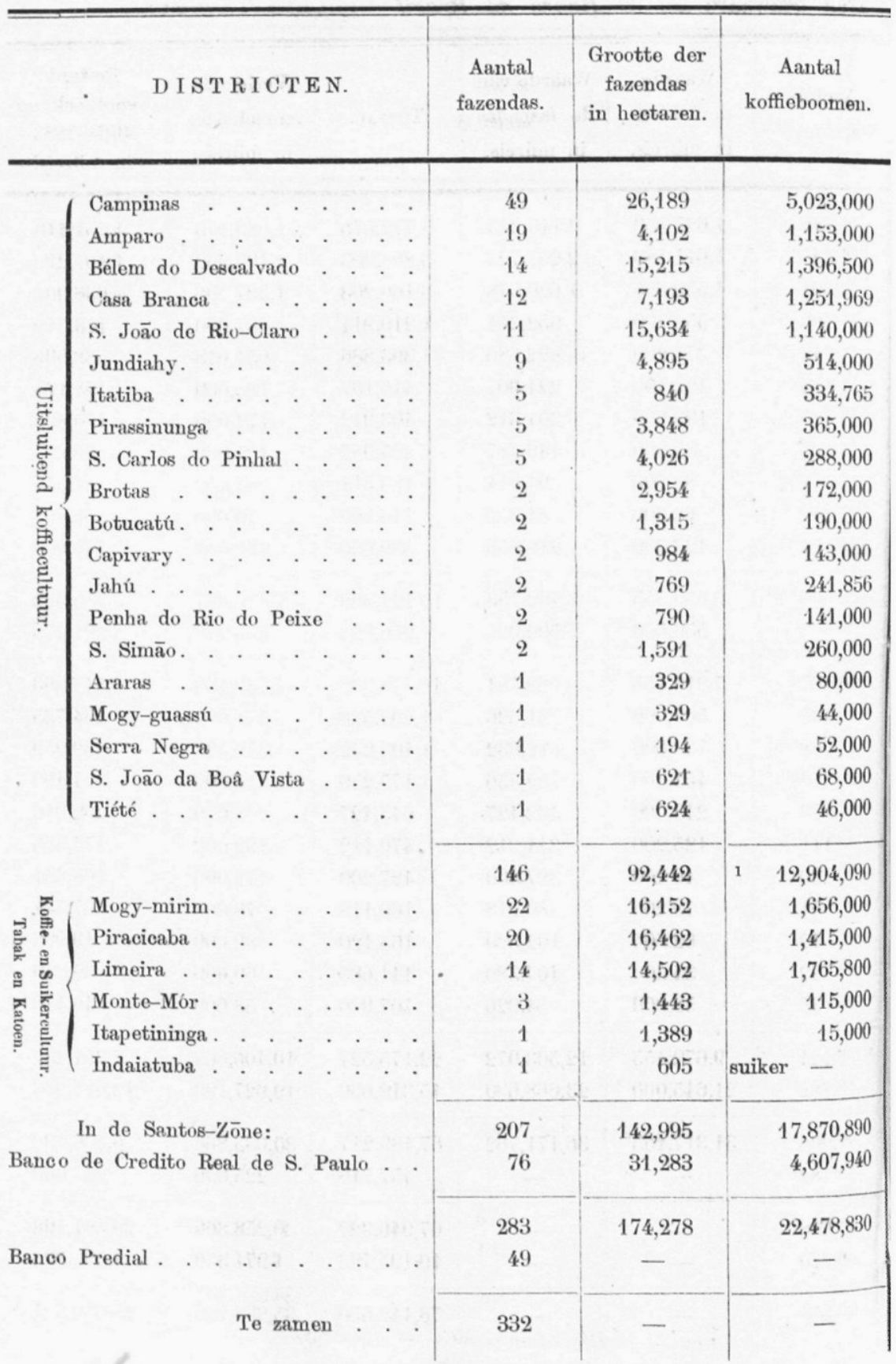

1 Een slaaf heeft dus te onderhouden 2450 boomen (gie koffiecultuur). 


\section{SANTOS-ZŌNE.}

S. Paulo op den 30n Juni 1883 waren bezwaard bij de Banco do Brazil.

\begin{tabular}{|c|c|c|c|c|c|}
\hline $\begin{array}{l}\text { Aantal } \\
\text { slaven. }\end{array}$ & $\begin{array}{l}\text { Waarde der } \\
\text { slaven } \\
\text { in milreis. }\end{array}$ & $\begin{array}{c}\text { Waarde van de } \\
\text { fazendas } \\
\text { in milreis. }\end{array}$ & $\begin{array}{c}\text { TотанL } \\
\text { in milreis. }\end{array}$ & $\begin{array}{l}\text { Verleende } \\
\text { voorschotten } \\
\text { in milreis. }\end{array}$ & $\begin{array}{c}\text { Restant } \\
\text { hypotheek op } \\
3 / 601883 \\
\text { in milreis. }\end{array}$ \\
\hline 2,613 & $3,662,200$ & $4,912,092$ & $8,574,292$ & $3,439,623$ & $2,270,908$ \\
\hline 397 & 575,100 & 944,820 & $1,489,920$ & 681,000 & 538,035 \\
\hline 486 & 695,300 & $1,438,888$ & $2,134,188$ & $1,034,000$ & 713,404 \\
\hline 461 & 631,200 & $1,073,817$ & $1,705,017$ & 812,000 & 749,776 \\
\hline 332 & 446,800 & 956,134 & $1,402,934$ & 668,000 & 404,299 \\
\hline 260 & 335,900 & 554,596 & 890,496 & 373,000 & 175,590 \\
\hline 108 & 168,300 & 245,869 & 444,169 & 201,000 & 181,149 \\
\hline 133 & 202,000 & 314,385 & 516,385 & 241,000 & 182,406 \\
\hline 88 & 123,800 & 252,069 & 375,869 & 175,000 & 107,232 \\
\hline 42 & 59,200 & 201,875 & 261,075 & 125,000 & 114,560 \\
\hline 32 & 49,800 & 201,361 & 251,161 & 110,000 & 94,557 \\
\hline 73 & 99,300 & 144,070 & 243,370 & 116,000 & 89,602 \\
\hline 72 & 117,200 & 185,992 & 303,192 & 148,000 & 141,799 \\
\hline 26 & 35,800 & 130,275 & 166,075 & 75,000 & 75,000 \\
\hline 31 & 43,800 & 197,658 & 241,458 & 115,000 & 115,000 \\
\hline 18 & 21,400 & 59,756 & 81,156 & 30,000 & 27,077 \\
\hline 14 & 21,700 & 40,256 & 61,956 & 25,000 & 23,200 \\
\hline 11 & 16,200 & 41,816 & 58,016 & 28,000 & 25,984 \\
\hline 35 & 43,100 & $81,4 \times 1$ & 124,541 & 60,000 & 58,602 \\
\hline 34 & 43,500 & 34,090 & 77,590 & 35,000 & 25,654 \\
\hline 5,266 & $7,394,600$ & $11,981,260$ & $19,372,860$ & $8,491,623$ & $6,113,834$ \\
\hline 682 & 929,200 & 1,536,793 & 2,465,993 & $1,105,870$ & 852,828 \\
\hline 1,103 & $1,297,300$ & $1,673,314$ & $2,970,614$ & $1,223,000$ & 837,544 \\
\hline 591 & 851,900 & $1,554,070$ & $2,405,970$ & $1,068,500$ & 733,721 \\
\hline 115 & 125,900 & 192,233 & 318,133 & 145,000 & 132,449 \\
\hline 26 & 37,100 & 52,394 & 89,491 & 44,000 & 36,147 \\
\hline 48 & 44,500 & 49,120 & 93,620 & 40,000 & 22,337 \\
\hline 7,831 & $10,677,500$ & $17,039,181$ & $27,716,681$ & $12,117,993$ & $8,728,860$ \\
\hline $1,196 i$ & - & - & $5,482,280$ & $2,613,000$ & $2,613,000$ \\
\hline 9,027 & - & - & $33,198,961$ & $14,730,993$ & $11,341,860$ \\
\hline 881 & - & - & $4,146,853$ & $1,957,100$ & $1,919,028$ \\
\hline 9,908 & - & - & $37,315,814$ & $16,688,093$ & $13,260,888$ \\
\hline
\end{tabular}


Uit deze staten zal men ontwaren: I

10. dat alléén in de Rio-Zōne verbonden zịnn:

569 fazendas bij de Banco do Brazil

6 " " " Banco de Credito Real de S. Paulo, en

132 " " Banco Predial, of te zamen

707 fazendas met 30,358 slaven, ter waarde van ruim 78 millioen milreis;

20. terwijl in de Santos-zōne:

207 fazendas bij de Banco do Brazil,

$76 "$ " " Banco de Credito Real de S. Paulo, en

49 " " Banco Predial, of te zamen

332 fazendas met 9,908 slaven, ter waarde van ruim 37 millioen milreis bezwaard zijn. 2

Een groot fazendeiro van S. Paulo, die algemeen geacht werd op de hoogte te zijn van den tegenwoordigen toestand, verzekerde mij dat men er op rekenen kon, dat slechts $20 \mathrm{pCt}$. van de tegenwoordige koffieondernemers vrij zijn, dat hoogstens 30 pCt. bij liquidatie hunne schulden zouden kunnen betalen, terwijl 50 pCt. thans reeds hopeloos staan en bij geen mogelijkheid er weder bovenop kunnen komen.

De koffiecultuur levert tegenwoordig geene, hoogstens zéér geringe winsten op.

De oud-minister en senator Diogo Velho, eigenaar van de fazenda "Fortaleza de Sant' Anna ", in Minas Geraes, met wien ik de eer had op die onderneming te spreken over den socialen, politieken en agrarischen toestand van het rijk, verzekerde mij o. a. - en op die verzekering kan men gerust afgaan, daar hij onder de weinigen behoort die juiste boeking hield van de uitgaven en ontvangsten zijner onderneming; dat een fazendeiro, die geheel vrij is, zich gelukkig mag rekenen, wanneer hij met hooge prijzen gemiddeld een winst van 1 milreis per arroba d. i $f 4,90$ per zak van 60 kilos kan maken. Dergelijke winsten behooren echter tot de groote uitzonderingen!

Daarentegen kan een fazendeiro van 80-100 slaven, die

1 Deze belangrijke gegevens werden mij verstrekt door de Presidenten en Directeuren van genoemde Banken.

Die van de twee eerstgenoemde Banken zijn op mijn verzoek opgemaakt.

Aan de Banco do Brazil heeft men, om mij ter wille te zijn, circa 4 maanden er aan gearbeid. Ruim 730 hypotheekcontracten met bijbehoorende stukken moesten daar worden nagezien om alles gedetailleerd te kunnen opgeven.

2 Zie omtrent de koffiezōnes het hoofdstuk over de koffiecultuur, waarin ook nader op deze staten zal worden teruggekomen. 
ongeveer 200 contos schuld heeft, bij geen mogelịkheid meer vrij worden, zelfs met zéér hooge prijzen.

De koffiecultuur in Brazilië kan bij zeer zuinig beheer en bij uitsluiting van alle niet strikt noodige uitgaven, nog een vrij goed bestaan opleveren aan de landbezitters die genoodzaakt zïn hunne gronden zelf te bebouwen, willen zij iets daarvan trekken.

Meer dan op Java toch zijn de grondeigenaars in Brazilië gedoemd, zich aan de koffieteelt vast te klampen. Fortuinen kan die cultuur niet meer afwerpen, hoogstens kan men met de tegenwoordige prijzen 10 à 12 pCt. van zijn geld maken. En dan moet men nog niet te ver van de havenplaatsen verwijderd zijn.

Volgens de "Relatorio da Associaçāo Commercial de Santos" van 1882, blz. 15, kan men de waarde van een fazenda, met een gemiddelde productie van 150,000 kilos stellen op:

De gronden . . . . . . 60,000 milreis

200,000 koffieboomen à 500 reis . 100,000 "

70 à 80 slaven . . . . . 100,000 "

gebouwen, machines, terreiros . . 40,000 "

Totaal . 300,000 milreis.

150,000 kilos koffie, tegen een netto provenu van $2 \$ 450$ per 10 kilos (of $f 17,64$ per zak) . . . . . 36,750 milreis

Onkosten op de fazenda en persoon lijke uitgaven

\section{Netto provenu}

$\frac{12,000 "}{24,750 \text { milreis }}$

dus $8 \frac{1}{4}$ pCt. van het kapitaal, een uitkomst welke voor de meeste fazendeiros die minstens 10 en 12 pCt. moeten betalen gelijk staat met verlies !

Ik wijs er op dat bij deze calculatie érstens gerekend is op een gemiddelden oogst van 750 grammen per boom of ruim 51 arrobas per 1000 boomen over den geheelen aanplant, (wat mijns inziens te hoog is, blijkens de gegevens voorkomende in het hoofdstuk "koffiecultuur") en ten andere dat daarbij niet in rekening wordt gebracht de waardevermindering, vooral van de slaven.

De transportkosten zijn zóó hoog, dat vele fazendeiros in het diepe binnenland vaak de inferieure soorten van hun product moeten aanhouden, om niet op den verkoopprijs toe te leggen.

In 1882 bijv. hebben de meeste koffieondernemers van de municipios Leopoldina, Mar d'Hespanha, Juiz de Fora (provincie Minas Geraes), Itapémirim, Victoria, S. Matheus (provincie Rio de Janeiro en Espirito Santo), Riberāo Preto, S. 
Simāo, Casa Branca (provincie S. Paulo) hun product met zwaar verlies moeten realiseeren.

De opbrengst was niet voldoende om de transportkosten te dekken, zoodat vaak de koffie in handen moest blijven van de Directiën der spoorwegen, die daarvan publieke veilingen moesten houden.

Men geeft zich van die transportkosten geen of niet genoegzaam rekenschap, wanneer men verklaart dat de koffie-zōne in welk land ook òngelimiteerd is in vergelijking van de koffieconsumptie. In Brazilië heeft men de uiterste grens van den aanplant reeds bereikt, zoo niet overschreden.

Bovendien, gelijk in het hoofdstuk over de koffiecultuur zal worden aangetoond en met cijfers, waarvoor ik kan instaan, bewezen, valt thans op geene uitbreiding van die cultuur meer te denken, zelfs voor het ondenkbare geval dat de koffieprijzen in de naaste toekomst verdubbelen.

Mocht Brazilië door eene verstandige regeling van de emancipatie-kwestie de slaven als arbeiders nog eenigen tijd behouden, dan kan zij de koffiecultuur op hare tegenwoordige hoogte handhaven, doch haar niet verder uitbreiden.

Gelijk ik hierboven aanteekende, hebben de fazendeiros de grootste moeite, om thans fondsen voor hunne ondernemingen te krijgen, daar zij bijna allen reeds bezwaard zijn. De voorwaarden waarop zij gelden op hypotheek kunnen bekomen, zijn bij alle hypotheekbanken nagenoeg dezelfde. Slechts de berekening der renten verschilt.

Zoo bijv. mag de Banco do Brazil volgens de bestaande overeenkomst met de Regeering niet meer berekenen dan 6 pCt. 's jaars voor een 20 jarige hypotheek, terwijl andere banken, bijv. de Banco de Credito real de $\mathrm{S}$. Paulo, 8 pCt. eischen voor de hypotheken van 5 tot 10 jaren en 9 pCt. voor die van $15-20$ jaren.

Gelijk men uit het hierachter gevoegde reglement van de Banco do Brazil kan ontwaren, moeten de wettelijke amortisaties en de betaling der renten jaarlijks plaats hebben op straffe van een boete bestaande in de berekening van 12 pCt. 's jaars instede van 6 pCt. Deze betaling geschiedt ò direct ò door tusschenkomst van den commissario, die er belang bij heeft dat alles geregeld afloopt. De jaarlijksche amortisatie bedraagt 5 pCt. van het oorspronkelijk geleend kapitaal, zoodat men het onschatbaar voorrecht heeft van ongestoord, gedurende 20 achtereenvolgende jaren, te kunnen doorwerken, en niet afhankelijk is van de zinnelijkheid van den hypotheek houder die, 
door het opeischen der gelden op een willekeurig oogenblik, het bestaan eener onderneming ten eenenmale kan vernietigen of minstens in de waagschaal stellen.

Niettegenstaande de hypotheekbanken op de fazendas gelden hebben , staan, maken zij geen bezwaar om de promessen van de verschillende eigenaars te disconteeren, zoo deze door een solieden commissario wordt geëndosseerd. De Banco do Brazil eischt thans echter twee soliede endossanten.

Ik geloof niet dat er ergens ter wereld, - minstens niet in Nederlandsch-Indië, - aan de landbouwondernemers zóóveel wettelijke waarborgen zijn gegeven om ongestoord hun landbouwbedrijf uit te oefenen, als juist in Brazilië. Dat zij met dat al in de laatste 5 jaren weinig zaken hebben gemaakt, moet uitsluitend worden toegeschreven aan de omstandigheid dat de werkkrachten zoo schaars en zoo duur zijn geworden.

Behalve door de hypotheekwet, worden zij bovendien nog om zoo te zeggen beschermd door een samenstel van wetten en gebruiken, dat, voor zoo ver mij bekend, nergens anders wordt aangetroffen. Zoo bijv. worden zij gewaarborgd tegen eene overhaaste gerechtelijke executie, férstens door den langzamen gang en de buitengewoon hooge kosten eener wettelijke vervolging, ten andere door de gevreesde gerechtelijke toewijzing. Alleen aan den deurwaarder (meirinho) betaalt men (evenals voor een doctorsvisite) 20 tot 30 milreis per legua of 6 kilometers; en daar zijn vele fazendeiros die 3 tot 4 leguas van bewoonde plaatsen afwonen.

De executie heeft eindelijk volgenderwijze plats. Op verzoek van den executant benoemt de rechter een commissie, die de onderneming plaatselijk moet gaan schatten. De gerechtelijke verkoop geschiedt alsdan, met inachtneming van alle wettelijke, zeer tijdroovende bepalingen, bij afslag. Doet er zich geen mijner op, dan wordt de verkoop eenigen tijd uitgesteld. Mocht bij dien tweeden verkoop weder geen liefhebber zijn, dan wijst de rechter de onderneming toe aan den executant tegen 75 pCt. van de geschatte waarde. Op die wijze wordt de ongelukkige ondernemer eenigszins gevrijwaard tegen alle bedekte speculatiën van de zijde zijner geldschieters.

In Brazilië kan het geval zich dus niet voordoen, - dat op Java wèl mogelijk is, - dat de executant een fazenda van 500 contos zèlf op publieke veiling koopt voor een paar milreis, en zijne pretentie op den geëxecuteerde behoudt.

Uit een en ander is het begrijpelijk dat men noode tot ge- 
rechtelijke vervolging overgaat, - ja vaak de voorkeur geeft aan afschrijving der schuld. Een braziliaansche fazendeiro die in moeilijkheden verkeert, wordt dáárom door zijn geldschieter en den hypotheekhouder gesteund en, zoo noodig, geholpen om er weder bovenop te komen. Hij kan rekenen op loyale medewerking om een crisis te boven te komen. In geen geval behoeft hij, gelijk de landbouwers op Java, de vrees te koesteren, dat juist zijn consignataris zich blindelings door de minder gunstige tijdsomstandigheden zal laten medeslepen om hem den genadeslag toe te brengen, door publiek den toestand van zijn fazenda zóódanig af te schilderen, dat hij nergens meer terecht kan en genoodzaakt is zich onvoorwaardelijk over te geven aan belangzuchtige speculanten.

Om een hypotheek op zijn fazenda te kunnen vestigen, heeft de eigenaar slechts eene gedrukte aanvrage in te vullen, en daarbij over te leggen :

1. zijn titel van eigendom;

2. de bewijzen van inschrijving (matriculatie) van zijne in de hypotheek op te nemen slaven;

3. een bewijs of verklaring dat de te bezwaren goederen nog niet ziju verhypothekeerd;

4. het bewijs of de verklaring dat hij geen voogd is van minderjarige weezen en, zoo hij het geweest is, het bewijs van acquit;

5. zijn huwelijksacte en de huwelijksche voorwaarden;

6. een inventaris zijner goederen op de onderneming;

7. den meetbrief van zijne onderneming, bekrachtigd door een rechterlijk vonnis of voor conform geteekend door zijne buren, wier gronden aan de zijne grenzen.

Tevens moet hij deponeeren een zekere som, welke de Bank noodig acht voor de kosten van de door haar te verrichten schatting, in den regel bedragende \pm 500 milreis per onderneming. De Bank heeft in de verschillende districten fazendeiros, die haar vertrouwen bezitten, en die zij met de schatting belast. Het door dezen in te dienen rapport wordt alsdan onderworpen (met het oog vooral op den meetbrief en de matriculatie-papieren der slaven) aan het oordeel van den advocaat der Bank. Overeenkomstig diens advies beslist zij. Wordt tot het geven van de hypotheek overgegaan, of van een gedeelte van de aangevaagde som, - zelden méér dan de werkelijke waarde der slaven, - dan geschiedt de uitbetaling gedeeltelijk in 
geld, gedeeltelijk in hypotheekbrieven van 100 milreis nominale waarde, rentende 6 pCt. 's jaars, betaalbaar eerst over het op de leening volgende halfjaar.

Bij de Banco do Brazil is niet bepaald hoeveel van de hypotheeksom in geld zal worden verstrekt. Dit wordt geregeld naar het aantal aanvragen en de beschikbare middelen.

Bij de Banco de Credito Real de S. Paulo is die hoeveelheid op 5 pCt. bepaald. Men krijgt daar 95 pCt. van de aangevraagde som in hypotheekbrieven. Deze brieven, betaalbaar aan toonder, moet de fazendeiro zelf te gelde maken, die zulks dan ook gewoonlijk doet naar gelang van de behoefte aan fondsen.

De koers van deze hypotheekbrieven bedraagt thans van de Banco de Brazil 99: $\frac{1}{2}$ pCt. (Mei 1884), van de Banco Predial 70 pCt. (Mei 1884), van de Banco de Credito real de S. Paulo 79 pCt. (Mei 1884).

Omtrent verdere détails gelieve men het hierachter gevoegd reglement van de Banco do Brazil na te zien.

De handel van Rio wordt op drieërlei wijze van koffie voorzien :

$a$. het product van het westelijk gedeelte van de provincie Rio de Janeiro, van Minas Geraes en het noordelijk gedeelte van Sāo Paulo, dat per spoorweg Dom Pedro II wordt aangevoerd;

$b$. het product van de provincie Espirito Santo, van het noordoostelijk en zuid-oostelijk gedeelte van de provincie Rio de Janeiro en voor een klein deel zelfs uit de kleine havens, tusschen Rio en Santos, dat door kusters of per " cabotagem " wordt geïmporteerd; en

c. het product van het centrale gedeelte van de provincie Rio de Janeiro, dat langs de Cantagallo, Rio Bonito en Principe de Grāo Para-lijnen wordt afgevoerd naar Sant' Anna do Murahy (nabij Nictheroy) en Mauá, en van dáár, metaan die lijnen behoorende stoomers, verder naar de trapiches wordt overgebracht; deze wijze van aanvoer heet die per "Barra Dentro."

Men heeft dus spoorwegaanvoer en importatie over zee en over de baai van Rio de Janeiro.

Gaan wij na, hoe die aanvoeren geschieden en welke kosten daarop vallen.

Zooals hierboven gezegd is, wordt de koffie eerst per "mulas 4 e Volgr. IX. Downloaded from Brill.com04/26/2023 12:44:16PM 
cargueiras " of muilezels of wel per overdekte kar, - dáár waar de wegen dit toelaten, - getransporteerd van de fazenda naar het station. Dat eerste transport is reeds zéér kostbaar, aangezien daarmede twee dagen verloren gaan voor de heen- en terugreis. Dat tijdverlies moet de fazendeiro betalen, aangezien de tropeiro op geen retourvracht kan rekenen. Aan het station wordt de koffie ontvangen door den agent of intermediario van den fazendeiro, zoo de stationchef zelf niet als zoodanig moet optreden, - gelijk het geval is op de D. Pedro II, en ook op de Leopoldina, de Uniāo-Mineira en andere particuliere lijnen, die, gelijk de twee laatstgenoemde, zelfs de zakken aan de fazendeiros verhuren voor 360 à 500 reis per zak en daarin een ruime bron van neveninkomsten vinden. In afwachting, dat men ze verzenden kan, worden de aangevoerde zakken koffie in een nevenlokaal van het stationsgebouw gedeponeerd, op den met plavuizen bekleeden grond, zonder eenige onderlaag, b. v. planken, gelijk op Java. Toezicht wordt daarbij weinig of niet gehouden. De zakken zijn niet dicht genaaid gelijk bij ons, maar de open zijde eenvoudig opgenomen en met een touwtje of liaan vastgebonden.

De intermediario of de stationchef weegt de zakken af; doet de eerste het, dan wordt zijn gewichtsopgave eenvoudig voor accoord aangenomen, en daarover de vracht berekend. Van hèrweging is alsdan geen sprake, men vertrouwt elkander gemakshalve. Dit kan men dan ook doen, omdat de spoorwegmaatschappij zich niet aansprakelijk stelt voor eventueele gewichtstekorten.

Dat op deze wijze vaak veel koffie verloren gaat, gelijk mij van verschillende kanten werd verzekerd, is begrijpelijk. De zakken toch zijn dikwịls oud en vol gaten, zoodat er veel gestort wordt onder de behandeling.

Verscheidene van die binnenlandsche intermediarios, gewoonlijk kleine tokohouders of herbergiers, vergenoegen zich bovendien niet met het opveegsel alléén, maar trachten ten koste van den fazendeiro nog wat te verdienen met het overzakken van de koffie, dat zij gewoon zijn te doen met den hoornen koffieschepper of cuia.

Cuia en rateio (verdeeling van den middenprijs) zijn twee woorden, die mij de koorts op het lijf jagen, zeide mij een fazendeiro.

Het vervoer per spoorweg geschiedt in afzonderlijke en gesloten 
wagons, op de D. Pedro II lijn van 9600 kilos, of de andere lijnen met smalspoor, gewoonlijk van 7000 kilos plaatsruimte.

Wordt de koffie met de D. Pedro II-lijn aangevoerd, dan wordt zij rechtstreeks gebracht naar de pakhuizen van de Gambô̂, alwaar zij voorloopig wordt opgeschuurd. Deze reusachtige pakhuizen, uitsluitend ten behoeve van den koffiehandel opgericht, beantwoorden niet geheel aan het doel, dat men zich bij het bouwen er van heeft voorgesteld. Zij zijn gelegen aan het "estaçāo maritima" van de D. Pedro II-lijn en moesten dienen tot opschuring van de koffie, die dan onverwijld zoude worden afgescheept. Men heeft er echter niet aan gedacht, of wèl men meende door uitbaggering gemakkelijk daarin te kunnen voorzien, dat het water hier niet diep genoeg is voor schepen van groot charter, gelijk de meeste koffietransportschepen zijn; dit is de reden, waarom de koffie hier niet wordt gelaten, maar vervoerd moet worden naar de respectieve pakhuizen der commissarios. Ik geloof niet dat er grooter pakhuizen dan de vorenbedoelde bestaan. Zij bestaan uit twee verdiepingen. De twee benedenpakhuizen, waarin men 60 à 70 duizend zakken koffie bergen kan, maar waar op het oogenblik, dat ik er was, nauwelijks 30 duizend balen waren opgestapeld, zijn voorzien van een ijzeren afdak aan den kant, waar de spoortrein aankomt.

De koffie wordt uit de wagons direct door de zijdeuren in het pakhuis overgebracht.

De twee bovenlokalen waren geheel ledig, zoodat ik eenige afmetingen nemen kon. De breedte bedraagt 39 van mijn gewone stappen, terwijl de lengte, door ijzeren pilaren in 29 gelijke vakken verdeeld, ruim 275 stappen bedraagt. In die lengte telde ik 29 vensters aan elken kant, terwijl in de breedte slechts 4 vensters zijn aangebracht. De trap bevindt zich op ongeveer $\frac{1}{3}$ van de lengte. Door een drietal groote luiken kunnen de koffiezakken machinaal naar boven geheeschen worden.

De commissarios hebben getracht deze twee bovenlokalen van het Gouvernement te huren, dat ze thans niet kan gebruiken, wijl de koffie, gelijk gezegd, hier niet opgeschuurd blijft, zoodat de twee benedenpakhuizen voldoende zijn voor den aanvoer uit het binnenland. Als huurprijs hebben zij het Gouvernement 6 pCt: van de bouwkosten aangeboden. De Regeering eischte echter, naar mij verzekerd werd, het drievoudige, zoodat tot heden daarvan niets is gekomen, 
In het begin van dit jaar, hebben eenige commissarios die van den rechtstreekschen uitvoer werk maken, der Regeering verzocht om de vergunning te mogen hebben, de uit het binnenland aangevoerde koffie, instede van 2 maal 24 uur, tien dagen in de Gamboâ-pakhuizen te mogen laten, in welken tijd gelegenheid te over bestaat om de koffie te verschepen. Vóór mijn vertrek was op dit verzoek nog geen beschikking ontvangen.

Het zou voor den koffiehandel zeker een groot voordeel wezen, indien de commissarios het product in deze pakhuizen konden bewerken voor den uitvoer zonder tusschenkomst van de ensaccadores, of indien zoo men bij rechtstreekschen uitvoer de kosten van transport binnen de stad kon sparen. Ook voor de in de nabijheid der pakhuizen wonende arme bevolking zou een dergelijke regeling een bron van ruime verdiensten opleveren. Kinderen en vrouwen zouden toch in dat geval met het uitzoeken van de koffie en ander licht werk gelegenheid hebben iets te verdienen.

De koffie, welke per "cabotagem" en "barradentro" aankomt, wordt opgeschuurd in de trapiches of groote pakhuizen nabij de kade in de rua da Saude.

De transportkosten, welke op dit product vallen, zijn aanzienlijk, gelijk men kan nagaan, wanneer men bedenkt, dat de koffie eerst van de fazenda getransporteerd moet worden naar de stations, van waar zij òf per spoor òf langs de Parahybarivier per stoomboot gebracht kan worden naar die plaatsen, van waar zij, hetzij met stoomschepen over de baai, hetzij per zeilvaartuig over zee, naar Rio kan worden vervoerd.

Het is schier ongelooflijk, en toch is het een feit, dat het watertransport van die koffie naar Rio hooger komt te staan dan het transport naar New-York of eenige haven in Europa. In die "trapiches" betaalt men 40 reis per zak voor elke acht dagen.

In den regel zijn die koffiesoorten, - hoofdzakelijk die van de provincie Espirito Santo en de lage streken van het noordoostelijk gedeelte van de provincie Rio de Janeiro, - van inferieure kwaliteit, (vaak gedurende de reis zoo geworden), en zoowel in Rio als in Europa bekend onder den algemeenen naam van "Capitania"-koffie.

Door eene vreemde regeling van de tarieven van eenige spoorwegen komt een vrij aanzienlijk gedeelte van den Saō Paulo-koffieoogst nog in Rio ter markt.

Ik heb zelfs afrekeningen van commissarios van die plaats Downloaded from Brill.comø4/26/2023 12:44:16PM 
voor mij van koffie, afkomstig van de verst afgelegen districten in genoemde provincie, bijv. Bélem de Descalvado.

Nog sterker, - koffie van het noordelijk gedeelte van de provincie São Paulo wordt vaak per spoor naar de hoofdstad van dien naam gezonden, om alsdan direct naar Rio te kunnen worden vervoerd. En zulks komt voor verschillende tusschenstations goedkooper uit, dan wanneer men het product van die plaatsen ò direct naar Rio ò direct naar Santos zendt.

Men , heeft dus hier het door de concurrentie in het leven geroepen feit, dat voor sommige plaatsen het goedkooper uitkomt, wanneer men het product langs een grooteren omweg, dan strikt noodig is, afvoert.

Ook oefent het verschil in prijs tusschen de markten van Rio en Santos daarop invloed uit. Die prijsverschillen schier altijd in het voordeel van Rio - zijn ook wel eens oorzaak dat men de koffie van Santos naar Rio ten verkoop zendt, gelijk mij o. a. werd verzekerd door de leden van de firma Johnston \& $\mathrm{C}$, een der vele groote koffie-exporthuizen van Rio.

Is de koffie te. Rio (en het éérste geldt natuurlijk ook voor Santos) aangekomen, dan moet men haar binnen 2 maal 24 uur van het spoorwegstation of binnen acht dagen van de kadepakhuizen laten afhalen.

Gewoonlijk begint een commissario met dadelijk na den ontvangst van den adviesbrief het daarbij gevoegde vrachtbiljet naar het kantoor van den spoorweg of van de trapiches te zenden, alwaar na betaling het document gestempeld wordt en men de partij kan doen afhalen.

Daar de partijen echter zeer ongelijk aankomen, - hetzij wegens gebrek aan wagons, bij groote aanvoeren, hetzij, gelijk in de maand Februari van dit jaar het geval was, de afvoer door aardstortingen of onderwaterzetting der baan tijdelijk gestremd is, - hebben de commissarios een bediende speciaal in dienst, om de vrachtbrieven te gaan betalen en te doen stempelen, en oin alle dagen te gaan informeeren of deze of gene partij reeds aangekomen is.

Is men niet diligent, en laat men de koffie langer dan 2 maal 24 uren aan de Gamboâ of langer dan 8 dagen in de trapiches, dan vervalt men in groote boeten en kosten.

Bij het in ontvangst nemen wordt het gewicht zelden of nooit geverifiëerd; - men telt eenvoudig het aantal zakken. 
Eenigen tijd heeft de Directie van de D. Pedro II-lijn, wegens de vele klachten over gewichtstekorten, de koffie doen wegen; maar ten behoeve van den handel moest men spoedig daarvan afzien, wijl men, naar het scheen, de middelen niet bezat om met den gewenschten en noodzakelijken spoed alles af te wegen. Het tijdverlies was kostbaarder dan het koffieverlies. Ofschoon het vrij algemeen beweerd wordt, zou ik toch niet durven verzekeren, dat hier van den kant der spoorweg-directie eenige tegenwerking bestond. Het gewichtsverlies moet echter zeer groot wezen, daar aanzienlijke hoeveelheden opveegsel (varredura) jaarlijks door de Directie worden verkocht en haar eere niet onaardige bate opleveren.

Dit viel zelfs zóó in het oog, dat, tijdens mijn verblijf te Rio in October 1883, daartegen werd geprotesteerd door al de betrokken commissarios. De betrekkelịke circulaire, welke ik bij een der commissarios opnam en bekeek, en waarvan de inhoud mij al dadelijk werd medegedeeld, was vol handteekeningen. Later daarnaar informeerende, werd mij verzekerd, dat bedoeld protest weinig doel had getroffen en de zaak verder gelaten werd, zooals zij was.

Het vervoer van de pakhuizen van de Gamboâ en de trapiches naar de verschillende pakhuizen der commissarios geschiedt per tram (smal spoor) door de "Companhia de Carris Urbanos".

Nabij het plein "Campo de Sant' Anna" splitst zich de lijn in zoovele zijlijnen als er wegen zijn, waar de commissarios, ensaccadores en exporteurs hunne pakhuizen en kantoren hebben. Deze dienst laat niets te wenschen over, zij is onverbeterlijk! De wagons zijn ongedekt; bij onverwachte regèns werpt men een geteerd zeildoek over de zakken.

Dezelfde maatschappij levert de dragers, die de koftie uit de wagons in het pakhuis van den ontvanger moeten brengen en opstapelen. Deze dragers zijn gewoonlijk Portugeezen of gehuurde slaven-negers. In den laatsten tijd beginnen ook de Italianen dat hand-, eigenlijk hoofdwerk uit te oefenen.

Aan de deur van het pakhuis - waarboven altijd het kantoor is - staat, nabij een tafel, een bediende, gewapend met de gevreesde furadór, een kolossale monstersteekpen, waarmede elke zak wordt doorboord, welken de drager op zijn hoofd binnen brengt, Deze handeling geschiedt zoo gezwind, dat de drager niet behoeft stil te staan. 
Dề monsters van gelijke kwaliteit en van dezelfde fazenda worden op één rij en in even zoovele hoopjes als er zakken zijn op de tafel gestort.

Van die "bona fide" monsters maakt men twee groote monsters van èlke soort en van èlke fazenda, elk monster van ongeveer $\frac{1}{2}$ kilo.

De monsters voor den verkoop (original) zijn gewikkeld in twee op elkander geplaatste stukken papier, het binnenste van een blauwe kleur, waarop zijn aangeteekend de nummers der zakken en de naam der onderneming, het buitenste wit.

De monsters voor den commissario, copia genoemd, worden slechts in een wit stuk papier gewikkeld, waarop hetzelfde wordt aangeteekend, doch met bijvoeging van de kwaliteit.

De kantoren van de verschillende commissarios zijn, om zoo te zeggen, even zoovele koffiebeurzen. De verkoop geschiedt gewoonlijk tusschen 8-10 uur 's morgens vóór het ontbijt.

In elk pakhuis heeft men een monsterkamertje, waar het licht van boven inkomt; men kent den invloed van het vallend licht op de kleur der koffie.

De ensaccadores, - de eigenlijke eerstehand-koopers, daar zij voor eigen rekening en risico zaken doen, - worden een voor een in het heiligdom toegelaten, waar zij op hun gemak alles kunnen zien en ongestoord met den commissario kumnen handelen.

De aanbiedingen geschieden volgenderwijze :

De commissario laat aan den aspirant-kooper zien al de origineele monsters van de verschillende fazendas, van de verlangde soorten en kwaliteiten. Aangezien de koffier-verzendingen uit het binnenland in zeer kleine hoeveelheden geschieden - gewoonlijk in partijen van 40,50 , ja zelfs van 10 en 25 zakken, - zoo gebeurt het altijd dat eer aantal van $20-60$ en ınéér monsters noodig is voor elken koop.

De ensaccador noteert voor zich de hoeveelheid zakken van elke kwaliteit, en doet dan een bod voor het geheel, voor de lote, welke het product uitmakt van verschillende ondernemingen.

Hoewel het bod in den regel per arroba gesehiedt, zoo worden de verkooprekeningen toch uitgeschreven per 10 kilos.

De commissario, die van zijn kant ook zịjne noteeringen heeft, accepteert of verwerpt dan het bod.

Gaat de ensaccador in het laatste geval weg, nadat hij zijn 
bod heeft hernieuwd of achtergelaten, dan heeft hij het recht van preferentie. Alsdan vermag een commissario. die zich zelf respecteert en zijn naam wenscht op te houden, de koffie niet aan een anderen kooper gunnen, dan tegen een prijs; minstens 100 reis per arroba hóoger dan het achtergelaten bod. De eerste bieder heeft dus een zeker voorrecht, wat de aanbiedingen natuurlijk zeer in de hand werkt en de realisatie van groote partijen, vaak van $\$ 0$ tot 80 duizend zakken in ééns, mogelijk maakt.

In de maanden September, October en November worden gemiddeld 10 tot 20 duizend zakken per dag verhandeld.

Onder de kleine misbruiken - die echter met het oog op den reusachtigen koffiehandel van Rio nog al opmerkelijk zijn - behoort o. a. het volgende aangeteekend te worden.

Daar, gelijk ik gezegd heb, de zakken alleen geteld, en onafgewogen aangenomen en afgeleverd worden, staan de commissarios altijd bloot aan reclames wegens gewichtstekorten van de zijle der ensaccadores. Deze kunnen evenwel de wettigheid van hun eisch evenmin bewijzen als aantoonen, aangezien ook zij het gekochte niet afwegen bij ontvangst. Eerst, wanneer zij de koffie hebben vermengd, verkocht en verzakt, komen zij vaak tot de ontdekking van die gewichtstekorteu. En, daar zij niet kunnen weten van welken commissario zij te weinig ontvangen hebben, slaan zij het bevonden tekort over al de commissarios, bij wie zij gekocht hebben. Deze weten dat, maar, ofschoon zij rechtens niet verplicht zijn tot eenige vergoeding, wordt alles toch in der minne geschikt, wijl ook zij overtuigd zijn, dat er gewichtstekorten kunnen bestaan. Bovendien geeft men vaak toe om de clandisie.

Langzamerhand hebben de ensaccadores zich echter het recht aangematigd, om reeds dadelijk eene vergoeding te eischen voor mogelijke gewichtstekorten, d. w. z. om op elke 100 zakken koffie 15 kilos toegift te krijgen.

Ofschoon aan die aanmatiging door de commissarios wordt toegegeven, omdat de koffie in den regel aan gewicht wint, voornamelijk in de vrij vochtige atmospheer van Rio, zoodat zij noch hunne committenten daarbij schade lijden, kan men deze handeling toch niet "fair" noemen, aangezien de fazendeiro daardoor wel geen schade, maar toch winstderving ondervindt. Op een export van vier of vijf millioen zakken is een dergelijke usance $\mathrm{m}$. i. niet te verdedigen. 
Verscheidene commissarios laten de koffie thans bij verkoop afwegen.

De verkoop tusschen commissarios en ensaccadores geschiedt in Rio nooit door tusschenkomst van den makelaar of corretor, en altijd op een termijn van twintig dagen of bij contante betaling tegen $\frac{1}{2} \mathrm{pCt}$. disconto.

In Santos, waar de exporteur rechtstreeks zijn koffie koopt van den commissario, meestal zonder de tusschenkomst van een makelaar, is de betalingstermijn op 30 dagen gesteld.

Van een dergelijken verkoop wordt nooit eene verkooprekening of brief opgemaakt; alles gaat op goed vertrouwen.

Wordt contante betaling niet aangeboden, dan wacht de commissario tot den een en twintigsten dag of in Santos tot den een en dertigsten dag, waarop hij dan over het verschuldigde beschikt.

Omtrent kwaliteit of prijs - zelfs voor het geval de marktwaarde achteruitgaat - komen nooit geschillen voor, gelijk mij niet van één, maar van verschillende zijden werd verzekerd. Zeer zelden gebeurt het zelfs, dat er refactie wordt gevraagd, en dan alleen voor het geval dat er eenige zakken zijn, die nat of door vochtigheid beschadigd zijn.

Chicanes, - zooals bijv. het aantreffen van eenige zwarte of gebroken boonen in een gekochte partij - worden niet opgeworpen, om van den koop af te komen of prijsvermindering te erlangen bij het dalen van de markt. In dat opzicht is de koffiehandel in Brazilië vèr verheven boven den onzen, waar blijken van kleingeestigheid en krenterigheid nu juist niet tot de uitzonderingen behooren.

Wanneer men de fazendeiros in de binnenlanden spreekt, dan duurt het niet lang of men moet de heftigste klachten over de commissarios en vooral de ensacccadores aanhooren.

Zijn die klachten gegrond? Of heeft men hier te doen met het gewone gemopper, vaak eigen aan hen, die lang buiten de gewone samenleving zijn gebleven, en, daardoor min of meer achterdochtig geworden, niet altijd een helderen blik kunnen slaan op den toestand, welken zij niet van nabij kennen?

Ziedaar vragen, welke ik gaarne had willen oplossen, maar die ik wegens den beperkten tijd, welke mij gegeven was, niet in staat ben, met volkomen zekerheid te beantwoorden. Tk acht het evenwel niet overbodig die klachten hier mede te deelen, ten einde zoo getrouw mogelijk aan de mij toevertrouwde missie te voldoen. 
In de éérste plaats dan klagen de fazendeiros steen en been over hunne van de commissarios ontvangen afrekeningen. Naar het heet, worden zij tekort gedaan in den verkoopprijs!

Men kan niet ontkennen, dat de commissarios een zekere, alléén door de practijk te verkrijgen handigheid en ervarenheid moeten hebben in de verdeeling of rateio van den middenprijs van een verkochte partij of lote, om geen aanleiding te geven tot reclames of ontev redenheid onder hunne koffie-v rienden. Zij moeten toch dien middenprijs splitsen in zóóvele prijzen als er fazendas en kwaliteiten in de partij zijn, wat zeker verre van gemakkelijk is.

Bij deze rateio worden zij gezegd zich zelven te betalen voor de verschillende faciliteiten en werkelijke voordeelen, die zij den fazendeiro toekennen, als b. v. :

1. het niet betalen van pakhuishuur, welke uitsluitend voor rekening komt van den commissario;

2. het niet betalen voor brandassurantie, welke deze alweder op zich neemt;

3. het niets betalen voor den post "porti, telegrammen en kleine onkosten", welke gemeenlijk in den handel een zeer geliefkoosde vorm van snijden is.

Daar zijn fazendeiros, die niet aan bepaalde consignaties gebonden zijn, "en daarom hun product ten verkoop zenden aan meer dan één commissario, met het doel, op die manier eenige contrôle op den verkoop uit te oefenen en tevens te speculeeren op de concurrentie tusschen humne agenten.

Nog een andere grief hebben zij tegen de commissarios en wel betreffende het gewicht.

Zij beweeren, dat er commissarios zijn, die niẹt genoeg er voor waken, dat bij het monstersteken te slordig met hun product wordt omgesprongen; éérstens door het toelaten, dat te groote monsters worden genomen, en ten andere door het door de vingers zien, dat hunne geëmployeerden - die aanspraak mogen maken op het opveegsel of varredura van het pakhuis wel eens hun tantième voorbedachtelijk laten aangroeien.

Ook de dragers moeten het ontgelden, daar zij door het schudden en eene zekere wijze van behandeling van den doorboorden zak het bedrijf van koffieopraapster op straat te gemakkelijk en voordeelig maken en zulks niet altijd uit zuivere menschlevendheid of aangeboren galanterie tegenover de oude negermnen, die zich in den regel daarmede bezighouden. Deze 
zijn vaak zoo onbeschaamd, dat zij de pakhuizen binnendringen om de gevallen koffie dáár op te rapen. Wịjl men ze niet slaan mag, worden zij gewoonlijk verjaagd door een straal water uit de spuit, welke iedere commissario aan de waterleiding voor den ingang van het pakhuis heeft.

Dit schijnt echter zeker te zijn, ten minste door verscheidene vertrouwbare personen, zelfs koffiehandelaren, werd zulks bevestigd, dat half Rio koffie drinkt, afkomstig van de varreduras of opveegsels van de verschillende pakhuizen

Het transport uit het pakhuis van den commissario naar dat van den ensaccador, en de nieuwe monstersteking aldáár, geschieden op dezelfde wijze, en, wat het érste betreft, mede door tusschenkomst van dezelfde Maatschappij, die er ook karren op na houdt voor die kleine trajecten, waar geen tramwagen loopt.

In den regel zijn de pakhuizen van deze koffiebaronnen nog ruimer dan die der commissarios. Moeten deze voor de huur hunner localiteiten, welke zelden in eigendom worden bezeten, van 4 tot 6 contos $(1$ conto $=f 1200)$ 's jaars betalen, gene moeten nog meer voor dien noodzakelijken post op hunne begrooting uittrekken.

De onkosten van pakhuishuur en personeel beloopen, volgens de ontvangen mededeelingen, tusschen de 25 à 45 contos, waaronder dan begrepen zijn de noodige uitgaven voor de tafel; aangezien, volgens de bestaande gewoonte, de commissarios hun bureau-personeel steeds met den kost engageeren en bovendien open tafel houden voor, en zelfs op de logies rekenen van de met hen in relatie staande fazendeiros, die om zaken, dan wel om zich te verzetten, tijdelijk de hofstad of Córte bezoeken. I

Daaı zijn ensaccadores en ensaccadores-firmas b. v. de maatschappij "Commercio e Lavoura", die pakhuizen bezitten, in ruimte weinig verschillend van de groote Gamboâ-pakhuizen.

De zooeven genoemde Maatschappij, die met een belangrịjk kapitaal hare zaken drijft, bezit in de Rua da Saude vier naast en met elkander in verbinding staande pakhuizen, waar men 100 tot 120 duizend balen koffie kan opstapelen. Deze Maatschappij exporteert hare koffie ook direct.

Ik zag in een van de benedenlokalen een reusachtigen berg inferieure koffie, zeker eene hoeveelheid van 10 tot 12,000

${ }^{1}$ Ofschoon de officieele vaam van Rio de Janeiro eigenlijk luidt: Muito Leal e Heroica Cidade Sāo Sebastiāo de Rio de Janeiro, zoo wordt deze stad in het dagelijksch leven, ook in schrifturen, kortweg genoemd Córte. 
pikols, die men bezig was met houten schoppen in nieuwe zakken te doen.

Op de zolders, boven de pakhuizen, had men bij mijne komst slechts eene hoeveelheid van 250 à 260,000 nieuwe zakken, otschoon die hoeveelheid in den regel grooter is volgens den pakhuismeester, die daar een kamer bewoont.

Ik zeide daar, dat men de koffie met houten schoppen in de nieuwe zakken doet. Dit wordt bij de groote ensaccadores weinig meer gedaan. Men deed het bij mijne komst, omdat de machineriën nog niet gesteld waren om alles werktuigelijk te kunnen verrichten

Naast de pakhuizen van bovengenoemde Maatschappij waren die van eene andere vereeniging van ensaccadores, wier werkkring hoofdzakelijk bestaat in het opkoopen van groote hoeveelheden inferieure koffie, ten einde die machinaal te doen sorteeren en bruineeren.

Ik was ooggetuige van die bewerkingen, die met eene bewonderenswaardige zekerheid en regelmaat afliepen. De commissario, die mij begeleidde, maakte mij in stilte opmerkzaam op eene, naar het schijnt ook door het Gouvernement verboden werkwijze, nl. die, om de verkleurde en slechtkleurige koffie door eene zekere zelfstandigheid een bepaalde tint te geven. 1 Daar de kunstmatig gekleurde koffie méér dan andere onderhevig is aan verkleuring, wordt die bewerking in den regel ook slechts toegepast op partijen koffie, die op levering verkocht zijn, doch iets noodig hebben, om geheel aan de gestelde eischen te voldoen. Men laakt deze werkwijze om de vaak voor de gezondheid schadelijke bestanddeelen, welke men daarvoor gebruikt, zoodat zij slechts in het geheim en steelsgewijze wordt toegepast.

1 Dat het kleuren van koffie algemeen wordt gedaan, minstens in NoordAmerika, blijkt uit het volgende uittreksel uit de "American Grocer and Dry goods Chronicle", New-York, 24 April 1884.

"Dr. Cyrus Edson of the New-York Board of Health, has been paying "special attention to the fraudulent coloring of coffee, and has discovered "that mineral poisons are freely used by several of the companies operating "in Brooklyn (N.-Y.) and which are to answer for their wrong practices to "the Board of Health of that eity."

"Arsenic, Venetian red, chromate of lead, ferro cyanide of potassium, and "Dmber are used tó color the beans."

"The bean being porous, or spongy, absorbs the arsenic and lead so "thoroughly, that it is almost impossible to remove it by any roasting or "eher ical process. If these mineral poisons remained upon the outside of "the bean, it would require a white heat to destroy them; and every dealer 
Om een denkbeeld te geven van den aanzienlijken omzet, teeken ik hier slechts ter loops aan:

1. dat er ensaccadores zijn, b. v. de firma Camara \& Gomes in de rua $\mathrm{S}$. Bento, die gemiddeld 100,000 zakken per maand mengen (liga) en verzakken en zulks door tusschenkomst van 27 machines, welke nog niet even zooveel personen behoeven oun alles te bewerken en zelfs machinaal af te wegen. Onder die machines zijn zoowel elevateurs om de gestorte koffie op of af te voeren als werktuigen om balen koffie van de beneden- naar de bovenpakhuizen te brengen; en

2. dat er koffiemakelaars zijn, zooals Rego \& Co te Rio, die meer dan 1 millioen zakken jaarlijks aan den man brengen.

Dat mengen van de koffie, ten einde een bepaalde middensoort koffie te erlangen, naar den wensch van den exporteur, b. v. door een regular, een $\mathbf{2}_{\mathrm{a}}$ boa en escolha te vermengen, ten einde de type ordinario te verkrijgen, is in het oog van den fazendeiro, die zooveel moeite en zorg heeft besteed voor het sorteeren van zijn product, de grootste grief tegen de ensaccadores. Dezen heeten zijn koffie te bederven!

Die klacht is naar mijne meening ongegrond.

Voor den fazendeiro moet het onverschillig zijn. wie zijn product koopt, zoo hij slechts een goeden prijs er voor maakt.

Welnu, de ensaccador is de plaatselijke koffieopkooper. Hij koopt en verkoopt koffie voor eigen risico. Niemand kan het hem in ernst kwalijk nemen, dat hij van zijn kant alles doet om het den exporteur - zijn afnemer - naar den zin te maken.

Van het standpunt van den koffieplanter, als individu, acht ik de klacht onredelijk.

De zaak krijgt echter een geheel ander aanzien, wanneer men haar van een meer oeconomisch standpunt beschouwt.

"knows that coffee is roasted in closed cylinders at a temperature, which "fails to volatilize any poisonous coating. It is incomprehensible how any firm "of good standing can be a party to such frauds."

en verder:

"Any artificial method, whether legitimate or illegitimate, can be used to "deceive, and we regret that so many reputable firms are practising fraud "upon retailers by using existing processes of manipulation.

"Large bean coffee of Mexican, Central-American, Vênezuelan or other "growth is made to imitate Java so closely as to defy detection except "by experts."

"That sort of swindling has become very common, and ve caution the "trade against "bargains" in old brown Government Java." 
Wat gebeurt er toch?

De eerstehand koffieopkoopers te Rio brengen de gesorteerde Brazilië-koffie niet op de wereldmarkt, zooals zij van de onderneming komt, waar men zich alle moeite getroost om door behandeling en sorteering de hoedanigheid te verbeteren, maar vermengd tot middensoort.

Op de wereldmarkten is dus geen eigenlijke fazenda-koffie te verkrijgen, maar slechts vermengde of liga-koffie.

Naar die kwaliteit wordt het product beoordeeld.

De aardachtige of terreiro-smaak komt naar mijne bescheiden meening hiervandaan, dat men vaak de escolha met goede soorten vermengd.

De escolha is de onoogelijkste koffie, welke ik ken, en op het oog slechts te vergelijken met de Bali-koffie, zooals zij te Soerabaia wordt aangevoerd, of met de koffie, welke in den handel gewoonlijk genoemd wordt rotte koffie.

De prijzen worden vastgesteld naar die middentypes en oefenen naturilijkerwijze invloed uit op de Braziliaansche markten.

De ensaccadores kunnen dus de werkelijke waarde van de uitstekend gesorteerde fazendakoffies niet aanleggen, wijl zịj nog de kosten hebben van de liga.

Op die wijze ondervindt de fazendeiro den terugslag van die handelsbewerking.

$\mathrm{Om}$ ze te voorkomen valt naar mijne overtuiging nicts anders te doen dan directe uitvoer, hetzij voor rekening van den fazendeiro, hetzij voor die van den commissario. In dien geest worden reeds proeven genomen, o. a. door den heer Vergueiro van Ibicaba, wiens product reeds in Hamburg en Bremen als Ibicaba-koffie bekend is, en door de commissarios Almeida \& Castro te Rio, die echter met schier onoverkomelijke bezwaren, zelfs van de zijde der fazendeiros van de Rio-zōne, te kampen hebben. Deze zijn toch, ofschoon zij klagen, zóó gewoon aan de oude sleur, dat men moeite heeft om hen over te halen tot eene proefneming. Verreweg de meesten kunnen zich bovendien die weelde niet gunnen, aangezien zij door humne consignatie-contracten en beloften tegenover den commissario gebonden zijn.

Dat een difecte export in het voordeel van den Braziliaanschen koffieplanter moet uitvallen, is niet te loochcnen, wanneer men weet, op welke wijze met de koffie aldaar wordt omgesprongen. 
Hieronder kan men zien, welke onkosten gemiddeld op een zak van 60 kilos vallen, wanneer men alles in rekening brengt.

Een directe export van fazenda-koffie op groote schaal kan in de eerste jaren evenwel niet plaats vinden. Gedeeltelijk om de hierboven opgegeven reden, gedeeltelijk omdat de groote importeurs van Europa en Noord-Amerika er voordeel in zien den bestaanden toestand te bestendigen. $\mathrm{Zij}$ toch doen het omgekeerde van wat de ensaccadores doen. Zij sorteeren de koffie weder naar kwaliteit, om de beste soorten onder beter bekende merken van de hand te doen. Evenals mousseerende rijnwijn griffer van de hand wordt gedaan, wanneer men hem duur verkoopt als echte Rhoederer of Carte Blanche, zoo wordt vaak ook het superieure Rio- of Santosproduct als Java of Ceylonplantation-koffie gesleten.

In Frankrijk b. v., waar men bijna niets anders over den tong krijgt dan gewone Brazilië-koffie, zal een koffiehuisjongen, waar ook, zich verontwaardigd toonen, wanneer men niet vast gelooft, echte en onvervalschte Mokka te drinken.

De verkoop tusschen de ensaccadores en de exporteurs, die schier allen zonder onderscheid orders uitvoeren en hoogst zelden voor eigen rekening zaken doen, geschiedt in Rio steeds, doch in Santos niet altijd door tusschenkomst van den corretor of makelaar.

De makelaar krijgt de order om naar een partij van zooveel en zooveel zakken van een bepaalde soort of type om te zien. Deze doet dan wat men noemt "het grove werk" van den koffiehandel. Hij loopt de kantoren van de ensaccadores af en doet informatiën.

Het is natuurlijk, dat, bij het beperkt aantal koffiemakelaars, want er zijn in Rio slechts drie van de vịf en dertig "corretores de mercadorias", die zich uitsluitend met den koffiehandel bezig houden en door wier tusschenkomst ruim $\frac{2}{3}$ van den export wordt verhandeld, deze dat werk niet alleen kunnen verrichten. Zij hebben dus humne adjudanten.

In den koffiehandel hangt de keuze van den makelaar af, van den kooper of exporteur en niet van den verkooper, gelijk bij verkoop van andere handelsartikelen.

De adjudanten der makelaars zijn in den regel vreemdelingen, die als zoodanig geen patent als makelaar kunnen krijgen; zij worden beunhazen of "zangōes" genoemd. Teder corretor heeft eenige van die "zangōes", die uitsluitend voor hem werken, tegen eene bepaalde percentage. Zij mogen wel transactiën sluiten 
voor den corretor, maar het koopcontract of makelaarsbriefje mogen zij niet teekenen. Eenige van die zangōes doen evenwel makelaarszaken voor eigen rekening; alsdan laten zij hunne transactiën onderteekenen door gepatenteerde corretores, die daarvoor een aandeel krijgen van de courtage.

Bij decreet van 10 Juni 1882 No. 8579 is het aantal makelaars voor Rio bepaald op 70, nl. 25 voor effectenhandel, 35 voor goederenhandel, 10 voor scheepszaken.

Vóór hunne benoeming moeten zij een bepaalde som als zekerheid storten; nl. de effecten-handelaars 10,000 milreis, en de goederen- en scheepsmakelaars 5,000 milreis.

De makelaars-commissie wordt geregeld volgens onderstaande tabel :

Staatseffecten, over de verkoopwaarde

Betaalbaar door:

Kooper. Verkooper .

Goud en zilver verkoopen, volgens koersbedrag . . . $\frac{1}{8}$ "

Wissels

Voor het disconteeren van wissels:

Van 4 maanden, over het bedrag

" 8

" 12

" boven de 12 maanden, volgens overeenkomst.

Suiker, over de verkoopwaarde

Koffie, per zak

$\frac{1}{8} \%$

$\%$

$\frac{1}{8} \%$

$\frac{1}{4} "$

$\frac{1}{8} "$

$\frac{1}{8} "$

Huiden, over de verkoopwaarde

Andere exportproducten

Verkoop van schepen

$\frac{1}{8} "$

$\frac{1}{4} "$

$\frac{3}{8} "$

$\frac{1}{2} "$

50 reis

50 reis

$\frac{1}{2} \%$

$\frac{1}{2} "$

-

$2 \frac{1}{2} \%$

Voor het charteren van schepen betaalt de eigenaar of agent $2 \frac{1}{2}$ pCt. over het bedrag van de vracht.

Voor het sluiten van verzekeringen betaalt de verzekerde $\frac{1}{10} \mathrm{pCt}$. over de verzekerde waarde.

Voor vertalingen van manifesten betaalt de eigenaar of agent 5 milreis voor elk van de 3 eerste pagina's en 2 milreis voor elk van de volgenden tot een maximum van 40 milreis.

Voor koersnoteeringen van één maand betaalt men 2 milreis, en het dubbele, zoo die noteeringen over eenige maanden loopen.

In Santos, waar men slechts een paar ensaccadores heeft, geschiedt de koffieverkoop zelden door tusschenkomst van de makelaars of van de zangōes. De transactiën worden hier meer rechtstreeks gesloten tusschen commissario en exporteur.

Ziehier de kosten, die een exporteur zijn principaal in rekening kan brengen. 
RIO DE JANEIRO.

Reis.

Prijs van de koffie.

" " " zak.

Vracht per zak (van het pakhuis naar de kade).

Courtage per zak

Capatazias per zak (kadegeld) .

Uitg. rechten $(4+7=11 \%)$

Kleine onkosten per zak . .

Telegramkosten per zak, in Rio 100 reis, bij groote orders minstens

Commissie

Wisselcourtage en zegel .

Brandassurantie (facultatief).

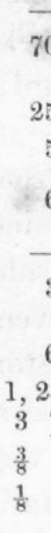

Reis.

SANTOS.

\begin{tabular}{|c|c|}
\hline - & pro memorie \\
\hline 800 & \\
\hline 300 & \\
\hline 50 & (facultatief) \\
\hline 60 & capatazias \\
\hline 30 & gem. belasting \\
\hline & pro memorie \\
\hline 100 & (vast) \\
\hline$\%$ & (vast) \\
\hline $3 \quad$ & \\
\hline$\frac{1}{8} \quad "$ & \\
\hline
\end{tabular}

De kosten van het overbrengen van de kade naar boord, alsmede die voor garneering, (gebruik van matten, hout of planken), en voor stuwage, komen te Rio voor rekening van het schip, aangezien al die kosten geacht worden begrepen te zijn onder den vrachtprijs.

In Santos daarentegen, waar men de koffie van het pakhuis naar boord moet brengen, betaalt men 50 reis per zak méér.

Weet de makelaar, waar de koffie van de verlangde type en hoeveelheid te krijgen is, dan waarschuwt hij zijn principaal, die dan over den koop met den ensaccador onderhandelt op dezelfde wijze als tusschen laatstgenoemde en den commissario.

Zoodra men het ook met den exporteur over kwaliteit en prijs eens is, vult de makelaar een paar gedrukte biljetten of verkooprekeningen in, en zendt die zoowel aan den kooper als aan den verkooper, daar hij zijne commissie, gelijk hiervoren is medegedeeld, van beiden ontvangen moet.

Alsdan heeft de liga of de vermenging en de overzakking in nieuwe zakken plaats.

De betaling geschiedt comptant bịj exportatie; tot zóólang blịft de koffie kosteloos in de pakhuizen van den ensaccador.

De termijn is eigenlijk twintig dagen; exporteert men niet binnen dien termijn, dan wordt pakhuishuur betaald volgens overeenkomst. Een eerdere verscheping geeft echter geen recht op disconto, gelijk bij contante betaling tusschen commissario en ensaccador.

Moet de koffie verscheept worden, dan geschiedt het transport van den ensaccador naar de afscheepplaats - "de Docas ke Volgr. IX. 
de Dom Pedro II" - voor rekening van den exporteur.

Nabij deze dokken heeft de Regeering zeer ruime en groote pakhuizen, waar de af te schepen koffie desverkiezende en tegen betaling kan worden opgeschuurd, totdat het oogenblik van afscheep gekomen is.

Het is hier de plaats met een enkel woord te spreken over eene handels-usance, welke immer aanleiding geeft tot het verschil in de export-cijfers, niet alleen volgens de officiëele, maar ook volgens de particuliere opgaven, gelijk mij o. a. ook door de chefs van de firma Ed. Johnston \& Co. en door den president van het Riosche syndicaat, den heer Berla, chef van het groote exporthuis Berla Cotrim \& Co., werd bevestigd.

Tk heb het oog op den guia-handel, d. i. de handel in koffie-passen.

Gelijk hierboven is aangestipt, behoort men bij koffie-export te betalen:

10. een provinciaal uitvoerrecht, bedragende voor Rio de Janeiro, Espirito Santo, Minas Geraes en Sāo Paulo 4 pCt. en voor de

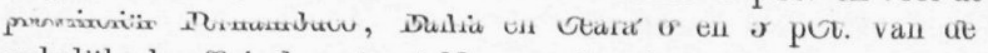
wekelijksch officieel vastgestelde waarde of pauta en

2o. een algemeen of staats-uitvoerrecht van 7 pCt. van bedoelde waarde.

Vóór den 20n Nov. 1882 was dit cijfer nog op 9 pCt. gesteld.

Welnu die provinciale uitvoerrechten worden in alle provinciën dadelijk bij den uitvoer over de grenzen betaald. Voor de uit de provincie Rio de Janeiro afkomstige koffie kan men desverkiezende de guia ook te Rio doen betalen.

Met het cognossement ontvangt de commissario ook den betaalden uitvoerpas of guia, zonder welke stukken hij de koffie niet in ontvangst kan nemen bij de spoorwegmaatschappij.

De verkoop van de koffie geschiedt zonder overlegging van de guias, die geldig zijn gedurende 60 dagen nà de afgifte. Dit zou dan ook in de practijk onmogelijk wezen.

Ook de exporteur krijgt zijne koffie zonder het bewijs van betaalde provinciale rechten. Bij den uitvoer. is hij evenwel genoodzaakt ò het bewijs te leveren dat die rechten wel betaald zijn, ò ten tweeden male de 4 pCt. bij te passen. Dit weten de geëmployeerden bij de douane, die met den export belast zijn. Deze ambtenaren (despachantes) koopen dáárom van de commissarios tegen lageren prijs dan de werkelijke waarde al de guias op, àe deze hebben en die nog niet vervallen zijn en verkoopen 
die passen met eene zekere winst weder aan de exporteurs. Zij verdienen op elke guia wel een kleinigheid, want ook de exporteur moet er voordeel in zien met guias te betalen, instede van de 4 pCt. in specie te voldoen; maar op den kolossalen uitvoer van Rio is de winst toch niet onbelangrijk.

Vele exporthuizen speculeeren ook in die guias. Een exporthuis bijv. dat een order heeft om over een maand eenige duizende zakken te verzenden en veronderstelt dat de koffieprijzen, derhalve ook de officiëele waarde of pauta, tegen dien tijd hooger zullen staan, koopt bij tijds de noodige guias en betaalt daarmede de douane. Deze neemt de guias aan, ook ter betaling van de 7 pCt. uitvoerrecht voor den Staat en geeft dan een bewijs af dat de $4+7=11$ pCt. rechten zijn betaald over zooveel duizend zakken. Die bewijzen zijn geldig voor 30 dagen.

Op die wijze kan het gebeuren, dat de export-opgaven van de douane en de verschillende firmas onderling vaak 100 tot 250,000 zakken en meer verschillen tegen het einde van het burgerlijk of van het dienstjaar. De douane toch berekent den uitvoer naar de betaalde rechten, terwijl de verschillende firmas dien regelen, hetzij naar den dag van afscheep in de haven, hetzij naar den dag van werkelijk vertrek uit de haven.

Gelijk ik hierboven zeide, laat de exporteur de af te schepen koffie tot aan de docas brengen. Daar heeft men een overdekte loods aan de kade. Daar betaalt men de capatazia of kadegeld en vertoont men de bewijzen dat de uitvoerrechten hetaald zijn.

Het transport van de kade naar en in het schip is, gelijk ik hierboven reeds aanteekende, begrepen in den vrachtprijs, welke op den 15 Februari 1884 bedroeg:

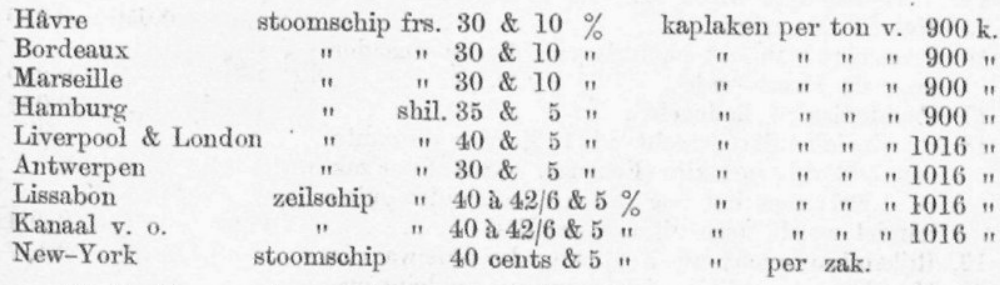

Uit het bovenstaande kan men lichtelijk nagaan, welke onkosten op de koffie vallen, alvorens zij Europa of Noord-Amerika bereikt.

Wanneer men naar waarheid en met de meeste nauwkeurigheid die kosten onder cijfers brengen moet, ten einde eene juiste vergelijking te kunnen maken met de kosten bij directen verkoop in Europa, dan zal men voorzeker geen goedkoopere be-

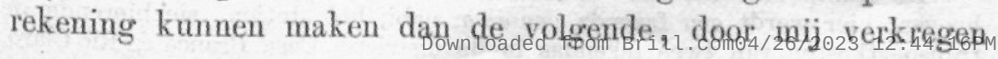


van een commissario, die gedurende ruim 20 jaren in den koffiehandel werkzaam is en van wien ik verscheidene zeer belangrijke gegevens ontvangen heb.

Stellen wij, dat de koffie afkomstig is van het station "Uba" aan den D. Pedro-II lijn: een uitgangspunt, dat vrij wel den gemiddelden afvoerafstand aangeeft van de drie groote koffieproduceerende provinciën, nl. 171 kilometer van Rio. Nemen wij verder aan, dat de afgevoerde hoeveelheid bedraagt een zak van 60 kilos ruim, afgewogen op de fazenda, dan zullen de kosten en winstderving voor den fazendeiro bedragen als volgt:

Berekening van de onkosten, vallende op 1 zak koffie, alvorens zij uit de haven van Rio geëxporteerd is.

1. Vracht van de fazenda naar het nabij gelegen station, gemiddeld ${ }^{1}$.

2. Vracht per spoor, volgens het verlaagde tarief v. 1882 , d. i. v. 171 kilom. $26 \$ 450$ p. 1000 k.

3. Zakkenhuur aan den intermediario of aan de spoorwegmaatschappij (inclusief commissie) .

4. Monsters en varreduras bij den intermediario of op het station $=1$ kilo, volgens de waarde $l_{\mathrm{a}}$ boâ

5. Varreduras gedurende de reis en in de pakhuizen van de Gamboâ $=\frac{1}{2}$ kilo volgens de waarde $1_{\mathrm{a}}$ boâ

6. Transport van de Gamboâ naar het pakhuis van den commissario.

7. Monsters en varreduras bij den commissario $=\frac{1}{2} \mathrm{k}$.

8. Verlies bij de rateio of prijsverdeeling . . .

9. Commissie ad $3 \%$ over Rs. $26 \$ 520$ verkoopprijs

10. Transport van het pakhuis van den commissario naar dat van den ensaccador.

11. Monsters, varreduras en toegift aan den ensaccador $=1$ kilo $\cdot$.

12. Onkosten van het mengen, verzakken en afwegen bij den ensaccador.

13. Prijs van den zak bij export. . . . . .

14. Vormoedelijke winst van den ensaccador.

15. Makelaarscourtage.

16. Transport van het pakhuis van den ensaccador naar de Docas-kade .

17. Capatazias of kadegeld .

18. Provinciale uitvoerrecht ad $4 \%$ over de pauta van 503 reis per kilo (Februari 1884) of per zak $=1.207$; met het oog op den bestaanden guiahandel wordt deze uitgaaf gesplitst

19, Rijksuitvoerrecht ad $7 \%$ over dezelfde waarde

20. Monsters, expeditie, telegrammen en kleine onkosten bij groote orders

21. Commissie v. d. exporteur, naar de overeenkomst, $1 \%, 2 \frac{1}{2} \%$ of $3 \%$ gem. $2 \%$ over $26 \$ 520$

22. Wisselcourtage en zegel $\frac{3}{8} \%$, stel over 32 milreis

23. Brandassurantie, tusschen koop- en exporttijd, in de laatste jaren in zwang gekomen $\frac{1}{8} \%$ over $32 \mathrm{~m}$.

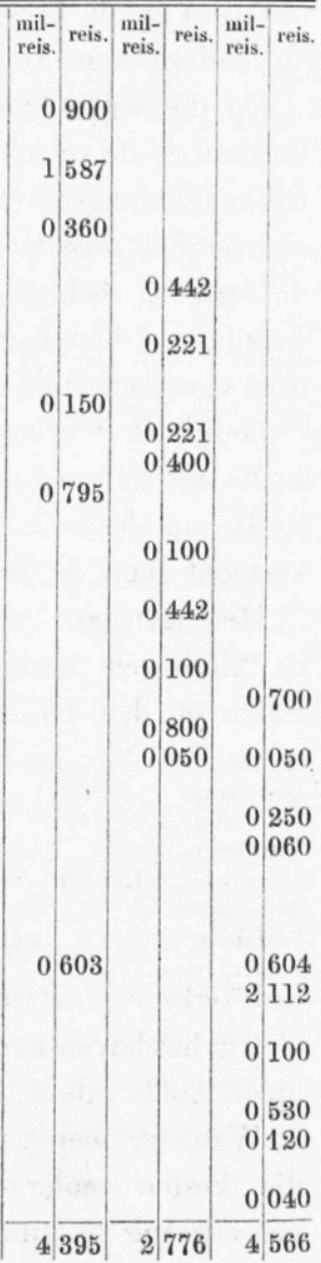

1 De transportkosten van de fazenda naar het station zijn gemiddeld véél hoogor; hier wordt een fazenda genomen nabij het station, yie hieronder de transportkosten van twee fazendas in de districten Casa Branca en Rio Claro 
Uit dezen staat blijkt:

1. dat de fazendeiro gemiddeld aan vervoerkosten en commissieloon op één zak eerste soort koffie ter waarde van $26 \$ 520$ moet betalen .

$4 \$ 395$ zoodat hij in den prijs van . . . . . . $\frac{.22 \$ 125}{.25}$ of $f 26,55$ moet terugvinden:

de bereidingskosten, de renten van zijn landbouwkapitaal, eene billijke afschrijving van de waarde zijner onderneming en slaven, zijne personeele uitgaven èn zijn winst!

2. dat hij, direct exporteerende, al dadelijk de niet onbelangrijke winst zou kunnen maken van $2 \$ 776$ per zak, welke thans voor hem verloren gaat.

3. dat de kosten van uitvoer zeer hoog zijn en gemiddeld gerekend kunnen worden te bedragen $4 \$ 566$ vermeerderd met . . . . . . $0 \$ 603$, aangezien de exporteur aan zijn principaal steeds in rekening brengt de volle $4+7=11$ pCt. uitvoerrechten. Deze laatste usance is de reden, waarom een exporteur bij groote orders zijn commissie lager kan stellen dan 3 of $2 \frac{1}{2}$ pCt.

Gelijk in het hoofdstuk "Koffiecultuur" nader zal worden aangetoond, kunnen de fazendeiros in Brazilië echter op geen 60 pCt. eerste soort koffie uit een oogst rekenen.

Een middenprijs van $26 \$ 520$ per zak, gelijk hierboven berekend is, wordt dan ook zelden gemaakt. De beste koffieondernemingen maken van haar product nog geen 25 milreis of $f 30$ per zak dooréén.

Volgens de Handelsvereeniging van Santos, waarin deskundigen als Würsten en Wright zitting hebben, schijnt een fazenda in de Santos-zōne zóóveel inferieure soorten af te werpen, dat men met de tegenwoordige prijzen, van een oogst van 150,000 kilos of 2500 zakken, slechts op een middenprijs mag rekenen van $14 \$ 700$ of $f 17,64$ netto per zak. (bl. 221).

De onkosten zijn dan ook zéér hoog.

Blijkens de voor mij liggende verkooprekeningen van een der voornaamste exporthuizen (dat direct zijn koffie uit het binnenland ontvangt), vallen op 1500 kilos of 25 zakken koffie uit de districten Casa Branca en Rio Claro de volgende kosten : 
10. Van Casa Branca, 358 kilometers van Santos: Vracht van de fazenda naar het station Casa Branca . . . . 90,Zakkenhuur en commissie te Casa Branca, 500 reis per 15 kilos. 50,Vracht en provinciale uitvoerrechten . . . . . . . . . 127,Onkosten te Santos, 20 reis per 10 kilos. . . . . . . . . 3,Commissie $3 \%$ over 750 milreis . . . . . . . . . . . 22,500 te zamen . . $292 \$ 500$ of per zak $f 14,04=. \quad 11 \$ 700$

20. Van Rio Claro, 275 kilometers van Santos:

Vracht van de fazenda naar het station Rio Claro . . . . . 110,Zakkenhuur en commissie aldaar, 500 reis per 15 kilos. . . . 50,Vracht en provinciale uitvoerrechten . . . . . . . . 100,Onkosten te Santos', 20 reis per 10 kilos. . . . . . . . . 3,Commissie $3 \%$ over 750 milreis. . . . . . . . . . . . 22,500

te zamen . . $285 \$ 500$ of per zak $f .13,70=. \quad 11 \$ 420$

Daaruit kan men zien, dat, zelfs bij vrij hooge prijzen van 5 milreis per 10 kilos, of $f 36$ per zak, het netto provenu niet groot is en aanleiding moet geven tot verlies. Commissie en vracht bedragen gemiddeld $38 \frac{1}{2}$ pCt. van de waarde.

Ten einde de kosten te kunnen nagaan, welke op de verschillende wereldmarkten bij verkoop van koffie berekend worden, heb ik hierachter als bijlage gevoegd eenige van verschillende firma's en van de consuls ontvangen verkooprekeningen, w. o. van Santos- en Java-koffie te Rotterdam. 